\title{
Review
}

\section{Valproic Acid and Breast Cancer: State of the Art in 2021}

\author{
Anna Wawruszak ${ }^{1, *(\mathbb{D},}$, Marta Halasa ${ }^{1}$, Estera Okon ${ }^{1}$, Wirginia Kukula-Koch ${ }^{2}$ and Andrzej Stepulak ${ }^{1}(\mathbb{D}$ \\ 1 Department of Biochemistry and Molecular Biology, Medical University of Lublin, 20-093 Lublin, Poland; \\ marta.halasa@umlub.pl (M.H.); estera.okon@umlub.pl (E.O.); andrzej.stepulak@umlub.pl (A.S.) \\ 2 Department of Pharmacognosy, Medical University of Lublin, 20-093 Lublin, Poland; \\ wirginia.kukulakoch@umlub.pl \\ * Correspondence: anna.wawruszak@umlub.pl; Tel.: +48-81448-6350
}

Citation: Wawruszak, A.; Halasa, M.; Okon, E.; Kukula-Koch, W.; Stepulak, A. Valproic Acid and Breast Cancer: State of the Art in 2021. Cancers 2021, 13, 3409. https://doi.org/10.3390/ cancers13143409

Academic Editors: Felisbina Queiroga and Bruno Cogliati

Received: 26 April 2021

Accepted: 5 July 2021

Published: 7 July 2021

Publisher's Note: MDPI stays neutral with regard to jurisdictional claims in published maps and institutional affiliations.

Copyright: (c) 2021 by the authors. Licensee MDPI, Basel, Switzerland. This article is an open access article distributed under the terms and conditions of the Creative Commons Attribution (CC BY) license (https:/ / creativecommons.org/licenses/by/ $4.0 /)$.
Simple Summary: Breast cancer $(\mathrm{BC})$ is the most common cancer diagnosed among women worldwide. Despite numerous studies, the pathogenesis of BC is still poorly understood, and effective therapy of this disease remains a challenge for medicine. This article provides the current state of knowledge of the impact of valproic acid (VPA) on different histological subtypes of BC, used in monotherapy or in combination with other active agents in experimental studies in vitro and in vivo. The comprehensive review highlights the progress that has been made on this topic recently.

Abstract: Valproic acid (2-propylpentanoic acid, VPA) is a short-chain fatty acid, a member of the group of histone deacetylase inhibitors (HDIs). VPA has been successfully used in the treatment of epilepsy, bipolar disorders, and schizophrenia for over 50 years. Numerous in vitro and in vivo pre-clinical studies suggest that this well-known anticonvulsant drug significantly inhibits cancer cell proliferation by modulating multiple signaling pathways. Breast cancer (BC) is the most common malignancy affecting women worldwide. Despite significant progress in the treatment of BC, serious adverse effects, high toxicity to normal cells, and the occurrence of multi-drug resistance (MDR) still limit the effective therapy of BC patients. Thus, new agents which improve the effectiveness of currently used methods, decrease the emergence of MDR, and increase disease-free survival are highly needed. This review focuses on in vitro and in vivo experimental data on VPA, applied individually or in combination with other anti-cancer agents, in the treatment of different histological subtypes of BC.

Keywords: breast cancer; valproic acid (VPA); histone deacetylase inhibitor (HDI); histone acetylation; histone deacetylases (HDACs); epigenetics; targeted therapy

\section{Introduction}

Regardless of socioeconomic status and level of development of societies, cancer is one of the most common causes of morbidity and mortality worldwide [1,2]. According to the GLOBOCAN, one in six women and one in five men were diagnosed with cancer in 2018 [1]. Unfortunately, the rates of cancer incidence and mortality are still rising. It is estimated that 13 million people will die from cancer in 2030 [3].

Breast cancer $(\mathrm{BC})$ is the most common cancer diagnosed among women in all regions in the world except in the eastern areas of Africa where cervical cancer occurs most often. Over the last twenty years, there has been an approximate $30 \%$ increase in the incidence rate of this disease [4]. Moreover, $\mathrm{BC}$ is the leading cause of neoplasms death in over 100 countries all over the world. In 2018, over 2 million new BC cases were diagnosed and nearly 630,000 deaths from BC have been reported worldwide [1,4].

Understanding the biological landscape of $\mathrm{BC}$ and its phenotypic heterogeneity is a key element in developing novel targeted therapies [5]. The integration of nucleic acid and peptide sequencing based on mass spectrometry and advanced biomolecular analysis allowing to define the post-translational modifications, provide a better understanding of 
the pathophysiology of $\mathrm{BC}$, and help to develop new more effective therapeutic strategies in the treatment of this disease [6]. Unfortunately, despite numerous studies, the pathogenesis of BC is still unknown, and effective therapy of this disease is one of the most important challenges of medicine.

Both genetic and epigenetic modifications are responsible for the progression of BC. Unlike irreversible genetic alterations, epigenetic modifications can be reversible. This suggests that epigenetic changes are favored in therapeutic applications. DNA methyltransferases and histone deacetylases are the main targets for epigenetic therapy. Several inhibitors of DNA methyltransferases and histone deacetylases have been approved by the US Food and Drug Administration (FDA) as anti-cancer drugs [7,8]. Reversible histone acetylation, catalyzed by histone acetyltransferases (HATs) and histone deacetylases (HDACs), plays an important role in epigenetic regulation of gene expression. An imbalance between HAT and HDAC expression leads to the development of numerous cancers $[8,9]$. In most cancer cell lines, a reduction in histone acetylation levels was observed due to overexpression of HDACs activity [10]. Histone deacetylase inhibitors (HDIs) are promising new generation cytostatics that increase histone acetylation. HDIs modulate the structure of chromatin, leading to changes in the expression of genes involved in numerous signaling pathways, including induction of apoptosis, cell cycle arrest, and inhibition of angiogenesis [11]. However, the mechanism of antitumor activity and the specificity of HDIs have not been fully understood.

In our review article, we described the current state of knowledge of the use of valproic acid (VPA), short-chain fatty acid, representative of the HDIs which has been successfully used in the treatment of epilepsy, bipolar disorders, and schizophrenia for over 50 years, individually or in combination with other active agents, in the treatment of $\mathrm{BC}$, with particular emphasis on the progress that have been done in this topic recently.

\section{Molecular Subtypes of Breast Cancers and Limitations in the Therapy of Patients Harboring These Subtypes}

$\mathrm{BC}$ is a complex group of diseases with specific pathological features and clinical implications. Extensive evidence suggests that BCs with varied biological and histopathological characteristics develop differently, resulting in miscellaneous responses to the treatment, and therefore various therapeutic strategies should be used [12-14].

Classic immunohistochemistry markers such as expression of estrogen (ER), progesterone (PG), and human epidermal growth factor (HER2) receptors; and clinicopathological factors, like tumor grade, size, nodal involvement, are conventionally used to select therapy and to predict disease progression. The widespread use of high-throughput techniques for gene expression analysis has shown that the response of cancer cells to treatment is not due to prognostic factors of anatomical origin, but to internal molecular characteristics of BCs $[12,15]$.

Five molecular subtypes of BC, including luminal A, luminal B, HER2-overexpressed, triple-negative and normal-like, were identified (Figure 1) [12,15]. 


\section{Main Intrinsic or Molecular Subtypes of Breast Cancer}

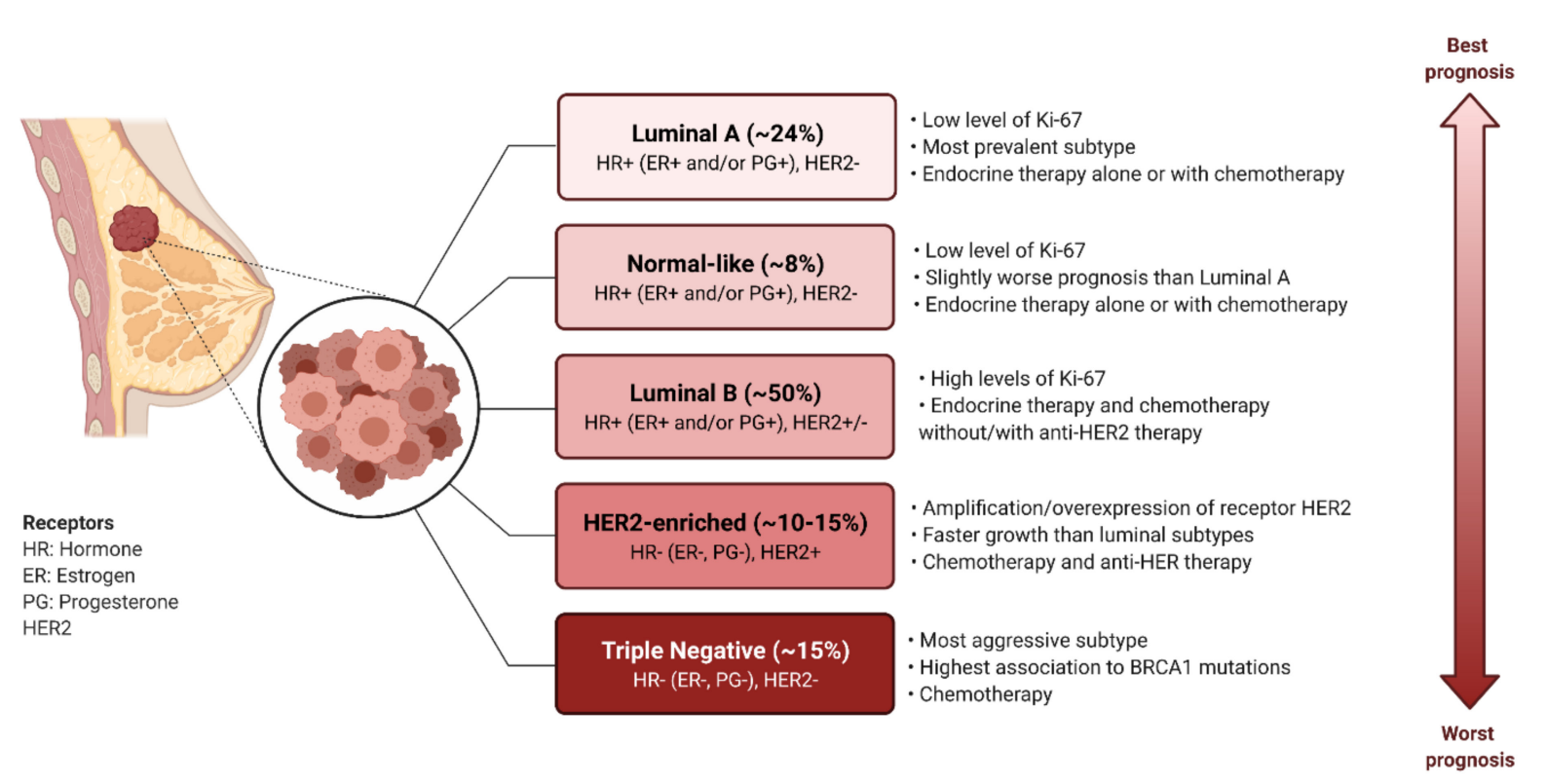

Figure 1. 5 main intrinsic or molecular subtypes of breast cancer (BC) (ER-estrogen receptor, PG-progesterone receptor, HER2-human epidermal growth factor receptor, Ki67-proliferation index marker) [12,13,16,17].

The hormone receptors (ER and PG) positive subtypes of BC are the most common types of breast carcinoma, among these luminal A and luminal B forms are more prevalent [18]. Luminal A BCs have a higher level of expression estrogen-related genes and lower expression of proliferative markers (Ki67 <20\%) compared to luminal B type (Ki67 $\geq 20 \%$ ). Moreover, luminal B cancers are usually characterized by higher histological grade than luminal A tumors. At the molecular level, luminal A subtypes are associated with somatic mutations in GATA3 (GATA binding protein 3), PIK3CA (phosphatidylinositol4,5-bisphosphate 3-kinase catalytic subunit alpha) and MAP3K1 (mitogen-activated protein kinase kinase 1) genes, and often exhibit cyclin D1 overexpression. Luminal B tumors show frequent mutations in the TP53 and PIK3CA genes as well as dysregulations in the retinoblastoma and MAPK (mitogen-activated protein kinase) signaling pathways [13]. Luminal cancers respond well to hormone-related therapies $[12,19,20]$.

Unlike the luminal type, HER2-overexpressed and triple-negative breast cancer (TNBC) subtypes are characterized by a lack of expression of ER and PG receptors, as well as high aggressiveness [18]. Although HER2-overexpressed BCs carry a poorer clinical prognosis compared to luminal subtypes, they have a much better response and sensitivity to anthracycline [21] and taxane-based neoadjuvant chemotherapy [22,23]. Even though the therapy of patients expressing HER2 receptors has been revolutionized by the introduction of anti-HER2 monoclonal antibodies (e.g., trastuzumab, bevacizumab, lapatinib) [24-26], recurrence and development of metastasis are serious clinical issues. In addition, not all patients with HER2-overexpression respond to therapy with trastuzumab. C-X-C chemokine receptor type 4 (CXCR4) up-regulation and phosphatase and tensin homolog (PTEN) loss are associated with resistance to treatment with trastuzumab. Therefore, new therapies are being sought for the treatment of cancers resistant to anti-HER2 monoclonal antibodies [12,27].

Approximately $15 \%$ of patients suffering from $\mathrm{BC}$ are diagnosed with its most severe form-TNBC. TNBC characterizes lack or low expression of hormone and HER2 receptors as well as a high level of basal markers, such as keratin or epidermal growth factor receptor (EGFR). There is also increased activation of the WNT signaling pathway and frequent mutations in the TP53 and BRCA1 genes [13]. Therefore, standard hormone therapies and targeted therapy directed against HER2 are excluded. TNBC characterizes a very 
aggressive clinical course, and a higher risk of local and systemic relapse [12,28-30]. TNBC has the worst prognosis of all the BC subtypes and is treated with systemic chemotherapy to which it responds better than other subtypes. Unfortunately, the use of traditional cytostatics (cisplatin, paclitaxel) is limited by numerous side effects (bone marrow damage, severe renal failure, peripheral neuropathies), as well as the occurrence of resistance to therapies [31-34]. Due to the lack of recognized molecular targets for therapy, TNBC is an object of interest for clinical trials with novel treatment approaches [13].

Normal-like type of BC accounts $7.8 \%$ of all cancer cases and characterizes similar immunohistochemistry status to the luminal A subtype (HR+ (ER+ and/or PG+), HER, low Ki-67) and normal breast tissue profiling. The tumor necrosis factor alpha (TNF $\alpha)$ pathway activity increased gradually from luminal A, luminal B, normal-like, HER2enriched and TNBC subtypes [35]. Still, while normal-like BC has relatively good prognosis, its outlook is slightly worse than luminal A cancers' prognosis [12]. Similar to the luminal A subtype, normal-like signature was found significantly less expressed in metastatic tumors than in primary tumors. It has been demonstrated that both normal-like and luminal A signatures show a negative correlation between time to tumor recurrence (TTR) and the magnitude of gene/signature expression changes between primary and metastatic disease [36]. Interestingly, normal-like cancer is less sensitive to paclitaxel- and doxorubicincontaining preoperative chemotherapy than the TNBC and HER2+ subtypes [37].

The presence or absence of receptors characteristic of BC allows to use of specific targeted therapies and the personalized treatment of BC patients. Targeted agents acting at the epigenetic level are currently being investigated in the treatment of different hematological malignancies and solid tumors.

\section{Histone Deacetylase Inhibitors (HDIs)}

The abnormal histone acetylation profile leads to numerous cellular disorders, including tumor initiation and progression [38]. It has been shown that histone acetylation disturbances are an important factor in the progression of BC. Studies linked with abnormal acetylation level of histones in BC focus on molecular mechanisms of BC development, identification of novel biomarkers for prediction aggressiveness of the tumor, and therapeutic potential [39].

Histone acetylation modifying enzymes control the transcription process by changing the status of histone acetylation as well as other transcription factors occurring mainly in the promoter region (Figure 2) [38]. Equilibrium in the activity of the opposing enzymes: HATs and HDACs is necessary to maintain epigenetic regulation of gene expression [40]. HATs catalyze the reversible acetylation reaction at the $\varepsilon$-amino group of lysine residues. Neutralization of the positive charge of lysine residues due to histone acetylation is correlated with chromatin relaxation and increased transcriptional activity of genes. Unlike HATs, HDACs remove acetyl groups leading to condensation of chromatin and silencing the transcriptional activity of genes (Figure 2) [8,41].

Based on the yeast protein homology and functional criteria, HDACs were divided into four classes: zinc- (I, II and IV) and NAD-dependent (III). HDACs 1, 2, 3 and 8 belong to the I class. The II class is divided into two subclasses IIa (HDAC4, 5, 7, 9) and IIb (HDAC6, 10). Class III due to homology to silent information regulator 2 (SIR2) of Saccharomyces cerevisiae is called sirtuins and includes SIRT1-SIRT7. Class IV contains only one member HDAC11 (Table 1) [8,41]. 

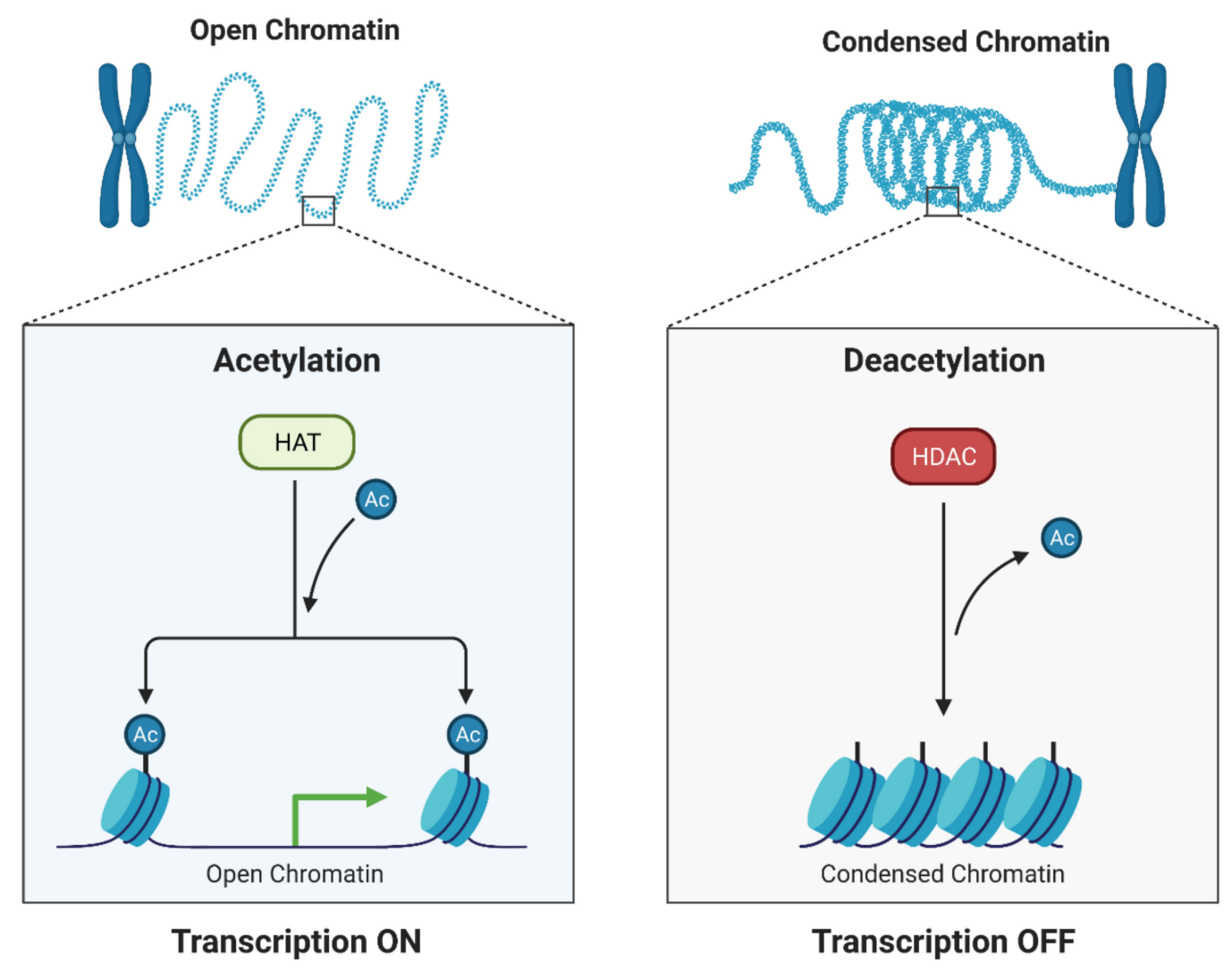

Figure 2. Histone acetylation modifying enzymes (HAT histone acetyltransferase, HDAD-histone deacetylase) control the transcription process by changing the status of histone acetylation and conformation of chromatin [38].

Table 1. Classification of histone deacetylases (HDACs) $[8,41]$.

\begin{tabular}{ccc}
\hline Class of HDAC & HDAC & $\begin{array}{c}\text { Zinc/Nicotinamide } \\
\text { (NAD)-Dependent }\end{array}$ \\
\hline I & HDAC1, 2, 3, 8 & zinc-dependent \\
II & IIa: HDAC4, 5, 7, 9 & zinc-dependent \\
III & IIb: HDAC6, 10 & NAD-dependent \\
IV & SIRT1-SIRT7 & zinc-dependent \\
\hline
\end{tabular}

Due to the fact that HDACs exert a significant effect on chromatin remodeling, their inhibitors (HDIs) have become an interesting field of study. HDIs are divided into four classes: hydroxamic acids (i.e., trichostatin A (TSA), vorinostat (SAHA), belinostat (PXD101), panobinostat (LBH-589), resminostat (4SC-201)); short chain fatty acids (i.e. sodium butyrate (NaB), phenylbutyrate (PBA), valproic acid (VPA)); cyclic peptides (i.e. apicidin (CAS183506-66-3), romidepsin (FK228)); benzamides (i.e. mocetinostat (MGCD103), entinostat (MS-275), domatinostat (4SC-202)) (Table 2) [10].

So far, four HDIs have been approved by the US Food and Drug Administration (FDA) for the treatment of certain types of cancer: SAHA-for the treatment of cutaneous manifestations of cutaneous T-cell lymphoma (CTCL) in patients with the progressive, persistent, or relapsing disease [42]; LBH-589-in polytherapy with bortezomib and dexamethasone for therapy of patients with relapsed and/or refractory multiple myeloma [43]; FK228 and PXD-101-for the treatment of peripheral T-cell lymphomas (PTCLs), a rare disease belonging to non-Hodgkin lymphomas [44,45]. Therefore, HDACs modulators may also be used as potential drugs in the BC treatment [39]. HDIs via inhibition of HDACs activity, increase the acetylation level of both histone and non-histone proteins [46,47] maintaining a global cellular acetylation profile which enables the activation of genes responsible for 
inhibiting the progression of $\mathrm{BC}$. Results from pre-clinical and clinical studies have shown that HDIs can induce different anti-cancer mechanisms in many types of $B C[8,40,41]$. Since VPA, as a psychoneurological drug, crossing the blood-brain barrier (BBC), it could also effectively eliminate metastatic BC cells in the brain of patients (Figure 3) [48].

Table 2. Classes of histone deacetylase inhibitors (HDIs) (CTCL-cutaneous T-cell lymphoma, FDA-Food and Drug Administration, PTCL-peripheral T-cell lymphoma) [10].

\begin{tabular}{|c|c|c|c|}
\hline Class of HDIs & HDI & Abrreviation & $\begin{array}{c}\text { FDA Approval for Cancer } \\
\text { Treatment }\end{array}$ \\
\hline Hydroxamic acids & $\begin{array}{c}\text { Tichostatin A } \\
\text { Vorinostat } \\
\text { Belinostat } \\
\text { Panobinostat } \\
\text { Resminostat }\end{array}$ & $\begin{array}{c}\text { TSA } \\
\text { SAHA } \\
\text { PXD-101 } \\
\text { LBH-589 } \\
\text { 4SC-201 }\end{array}$ & $\begin{array}{c}\text { Approved for CTCL treatment } \\
\text { Approved for PTCLs treatment } \\
\text { Approved for multiple myeloma } \\
\text { treatment }\end{array}$ \\
\hline Short chain fatty acids & $\begin{array}{l}\text { Sodium butyrate } \\
\text { Phenylbutyrate } \\
\text { Valproic acid }\end{array}$ & $\begin{array}{l}\mathrm{NaB} \\
\mathrm{PBA} \\
\mathrm{VPA}\end{array}$ & \\
\hline Cyclic peptides & $\begin{array}{c}\text { Apicidin } \\
\text { Romidepsin }\end{array}$ & $\begin{array}{c}\text { CAS183506-66-3 } \\
\text { FK228 }\end{array}$ & Approved for PTCLs treatment \\
\hline Benzamides & $\begin{array}{l}\text { Mocetinostat } \\
\text { Entinostat } \\
\text { Domatinostat }\end{array}$ & $\begin{array}{l}\text { MGCD103 } \\
\text { MS-275 } \\
\text { 4SC-202 }\end{array}$ & \\
\hline
\end{tabular}

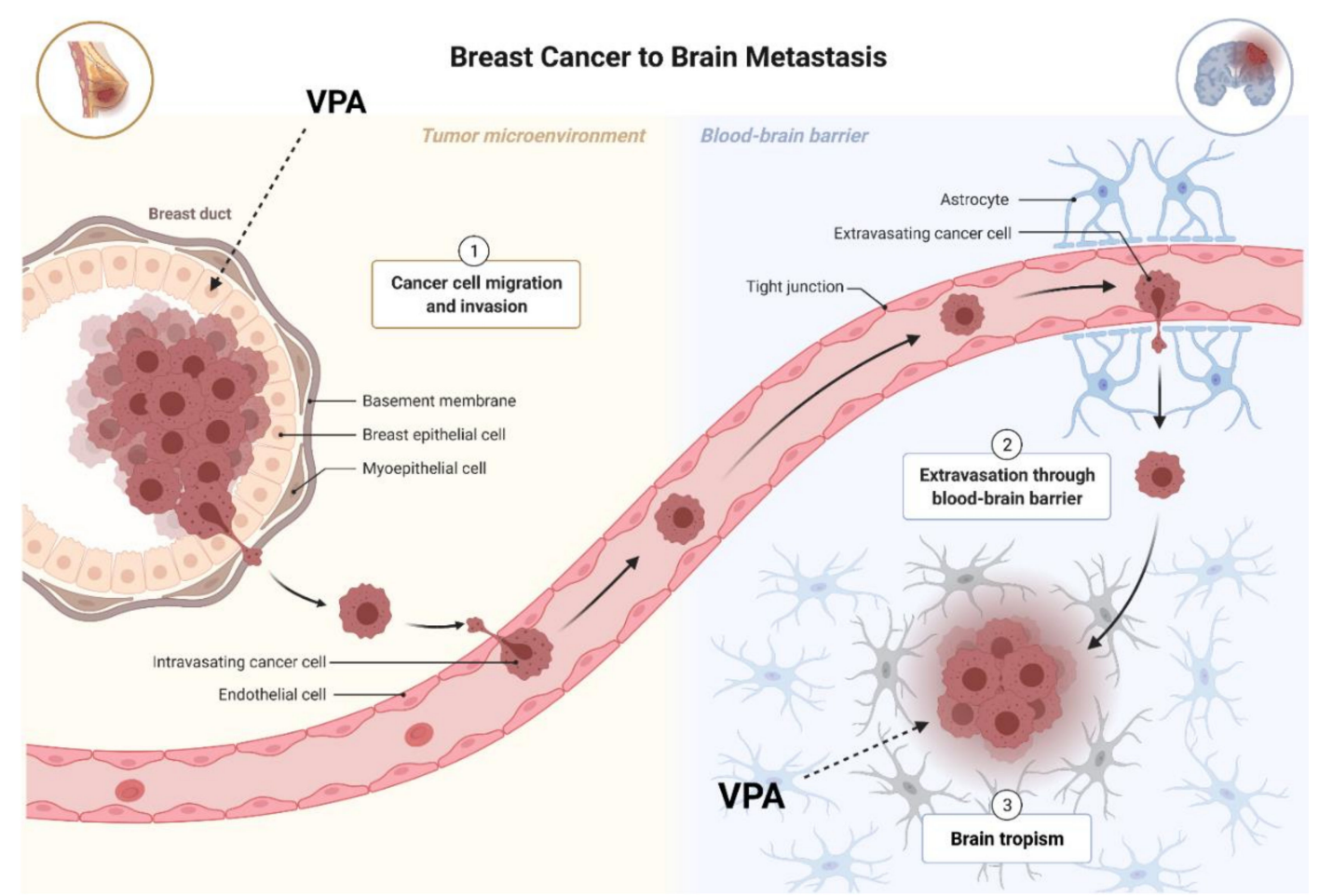

Figure 3. The potential effects of valproic acid (VPA) on breast cancer cells and metastatic breast cancer (BC) cells in the brain.

HDIs are able to inhibit proliferation and induce the differentiation and apoptosis of tumor cells resistant to different cytostatic drugs by regulating the expression several genes. It was already demonstrated in 2004 that administration of TSA to BC cells resistant to tamoxifen caused an increase in estrogen receptor expression, which in turn allowed for re-sensitization of these cells to the administered drug [49]. In addition, it has been shown that new synthetic HDI-FA17 overcome multidrug resistance (MDR) in BC cells of 
the MCF-7/MTX insensitive to methotrexate cell line [50]. In general, HDIs can induce tumor growth inhibition and apoptosis of tumor cells. Interestingly, in opposite to standard cytostatic agents, HDIs show significantly lower toxicity to normal cells $[8,40,41]$.

\section{Valproic Acid and Breast Cancer}

Valproic acid (2-propylpentanoic acid, VPA) belongs to the group of short-chain fatty acids. VPA causes acetylation of the N-terminal tails on histones $\mathrm{H} 3$ and $\mathrm{H} 4$, and inhibits the activity of HDAC I and II, probably by binding to the catalytic center, and in consequence, blocking access to the substrate [8,51]. VPA has been approved by the FDA for the treatment of epilepsy and other convulsive diseases and has been used successfully in the therapy of these diseases for over five decades [52]. It has been demonstrated that VPA shows anticancer activity (Figure 4) in a diversity of human cancers [53-55], including breast carcinoma [56-59].

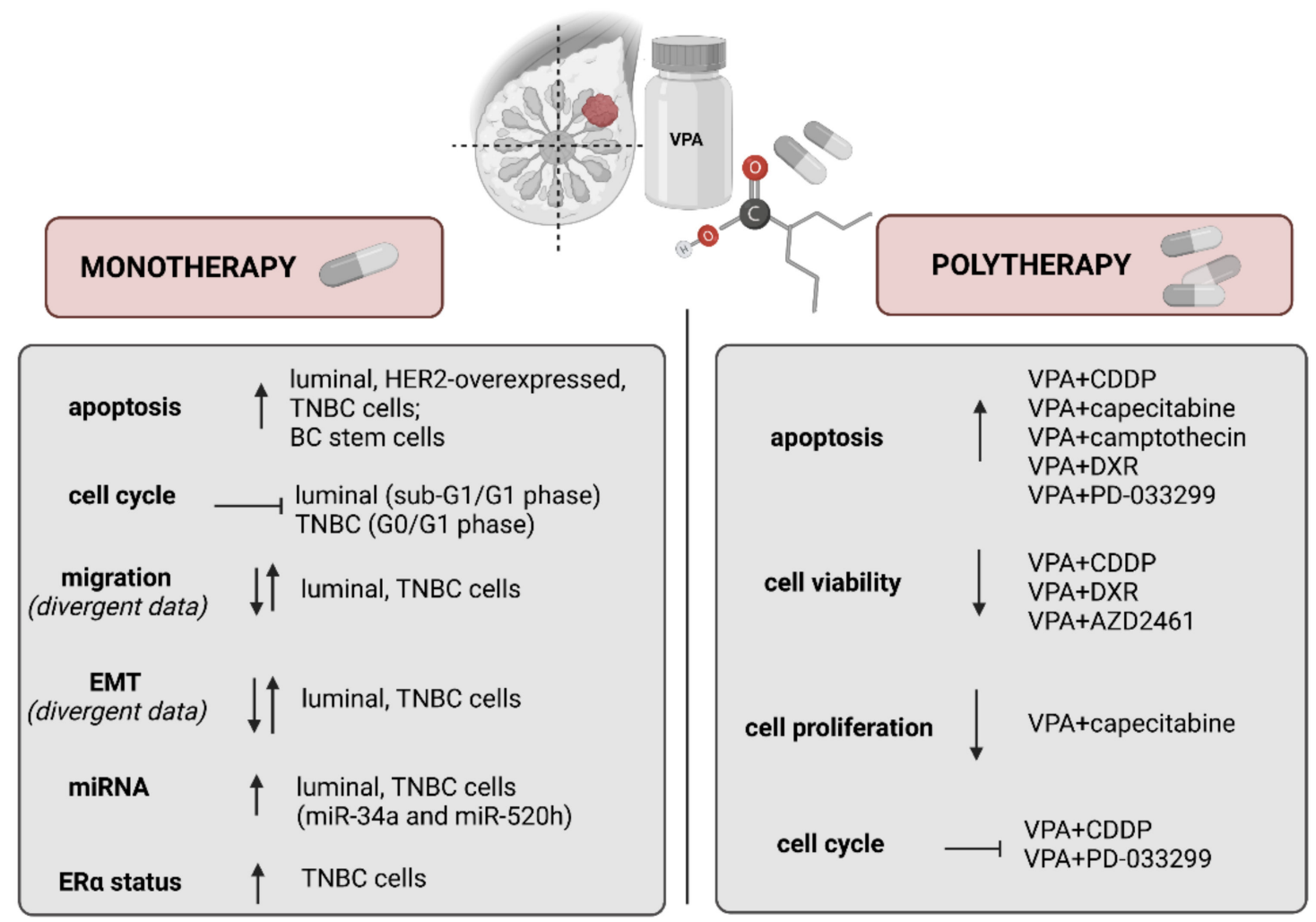

Figure 4. The functional mechanism of valproic acid in breast cancer treatment (BC-breast cancer, CDDP-cisplatin, DXRdoxorubicin, ER-estrogen receptor, EMT-epithelial-mesenchymal transition, HER2-human epidermal growth factor receptor 2, TNBC-triple-negative breast cancer, VPA-valproic acid) ( $\uparrow$-increase, $\downarrow$ —decrease, ——stop).

\subsection{VPA Induces Apoptosis and Inhibits Cell Cycle}

VPA decreases cell viability through arresting of the cell cycle in G1 or sub-G1 phases, induction of p21 protein expression and apoptosis by upregulation of Bak, downregulation of Bcl-2 expression, increasing $\mathrm{Bax} / \mathrm{Bcl}-2$ ratio, and, as a consequence, decreasing telomerase activity in estrogen-positive MCF7 BC cells. Telomerase is a ribonucleoprotein reverse transcriptase involved in the elongation of the telomeres and is responsible for the phenomenon of resistance to apoptosis in cancer cells $[60,61]$. VPA reduced proliferation not only MCF-7 BC cells but also MCF-7 BC stem cells in a time $(24,48,72 \mathrm{~h})$ and dose (0.6-20 mM) dependent manner. Cancer stem cells (CSCs) are a subpopulation of cells that reinitiate carcinogenesis, induce resistance to chemotherapy, are prone to develop metastases, and lead to disease relapse due to acquired resistance to apoptosis. Epigenetic alterations play a pivotal role in the regulation of stemness and also have been implicated 
in the development of drug resistance. It has been detected that MCF-7 stem cells were much more resistant to VPA than MCF-7 cells. Moreover, VPA increased levels of M30 protein (cytokeratin 18 neoepitope), caspase 3 and 7 activations, annexin-V-FITC positivity, suggesting apoptosis induction in BC stem cells. The late stage of apoptosis (secondary necrosis) was also evidenced by nuclear pyknosis with propidium iodide staining [61].

Similar to receptor-positive BCs, VPA induces cell cycle inhibition and apoptosis in BC cells with HER2 overexpression. HER2-overexpressed BC cells are more sensitive to VPA than HER2-negative ones. It has been demonstrated that the anti-proliferative mechanism of VPA in BC cells is related to their HER2-expression status. Therefore, VPA may synergize with drugs used in the therapy of HER2-overexpressed BC, like anti-HER2 monoclonal antibodies (e.g., trastuzumab, bevacizumab, lapatinib) or anthracycline and taxane-based neoadjuvant chemotherapy to inhibit HER2-overexpressing BC cell proliferation more effectively. The antiproliferative effect of VPA results from Hsp90 dysfunction which is involved in hyperacetylation of Hsp70 (non-histone protein acetylation). Hyperacetylation of Hsp70 directly affects the HER2 receptor protein, which is the client of the Hsp90 protein. The loss of Hsp90 function leads to the degradation of Hsp90 client proteins and the process of apoptosis. The alteration of the level of cyclin-dependent kinase inhibitor p21/WAF1, cleaved caspase-3, acetylated heat shock protein (Hsp) 70, acetylated Hsp90, and acetylated $\alpha$-tubulin by VPA was determined in SKBR3 HER2-overexpressing BC cells. It has been observed that VPA upregulates expression and induces targeting of p21 WAF1, cleaved caspase-3, upregulates Hsp 70 acetylation, inhibits differentiation, and exhibits antiproliferative activity in BC cells in a dose- and time-dependent manner [8,62]. It has been demonstrated that VPA also remarkably inhibits the growth and triggers apoptotic cell death through G0/G1 arrest in MDA-MB-231 TNBC cells (Table 3) [57].

Table 3. Mechanism of action of valproic acid (VPA) in in vitro breast cancer (BC) pre-clinical setting (BC-breast cancer, EMT-epithelial-mesenchymal transition, ER-estrogen receptor, HER-2-human epidermal growth factor receptor 2).

\begin{tabular}{|c|c|c|c|c|}
\hline Cellular Process & Sub-Type of BC & Cell Line & Mechanism of Action & References \\
\hline \multirow{4}{*}{ Apoptosis } & \multirow{2}{*}{ Luminal } & MCF7 & $\begin{array}{c}\uparrow \text { apoptosis }(\uparrow \mathrm{p} 21, \uparrow \mathrm{Bak}, \\
\uparrow \mathrm{Bax} / \mathrm{Bcl}-2 \text { ratio, } \downarrow \mathrm{Bcl}-2 \text { proteins } \\
\text { expression, } \downarrow \text { telomerase activity) }\end{array}$ & {$[60]$} \\
\hline & & MCF7 tem cells & $\begin{array}{c}\uparrow \text { apoptosis ( } \uparrow \mathrm{M} 30 \text { protein } \\
\text { expression, } \uparrow \text { caspase } 3 \text { and } 7 \\
\text { activation, } \uparrow \text { nuclear pycnosis) }\end{array}$ & [61] \\
\hline & HER-2-overexpressed & SKBR3 & $\begin{array}{c}\uparrow \text { apoptosis ( } \uparrow \text { cleaves caspase } 3, \\
\uparrow H \text { sp70 acetyaltion) }\end{array}$ & {$[62]$} \\
\hline & TNBC & MDA-MB-231 & ヤapoptosis & [57] \\
\hline \multirow{4}{*}{ Cell cycle } & \multirow{2}{*}{ Luminal } & MCF7 & cell cycle arrest in sub-G1 phase & {$[60]$} \\
\hline & & ZR-75-1 & cell cycle arrest in G1 phase & {$[60]$} \\
\hline & HER-2-overexpressed & SKBR3 & $\uparrow \mathrm{p} 21 \mathrm{WAF} 1$ protein expression & [62] \\
\hline & TNBC & MDA-MB-231 & cell cycle arrest in G0/G1 phase & [57] \\
\hline \multirow{5}{*}{ Migration } & \multirow[b]{2}{*}{ Luminal } & MCF7 & $\uparrow$ migration & [63] \\
\hline & & $\begin{array}{l}\text { MCF7 } \\
\text { T47D }\end{array}$ & $\downarrow$ migration & [64] \\
\hline & \multirow{3}{*}{ TNBC } & MDA-MB-231 & $\begin{array}{l}\downarrow \text { migration }(\uparrow n m 23 H 1 \text { gene } \\
\text { expression) }\end{array}$ & [65] \\
\hline & & $\begin{array}{l}\text { MDA-MB-231 } \\
\text { MDA-MB-468 }\end{array}$ & $\downarrow$ migration & [64] \\
\hline & & MDA-MB-231 & $\uparrow$ migration & {$[57,63]$} \\
\hline
\end{tabular}


Table 3. Cont.

\begin{tabular}{|c|c|c|c|c|}
\hline Cellular Process & Sub-Type of BC & Cell Line & Mechanism of Action & References \\
\hline \multirow{5}{*}{ EMT } & \multirow{2}{*}{ Luminal } & MCF7 & $\begin{array}{c}\uparrow E M T(\uparrow S n a i l, \uparrow Z e b-2 \text { genes } \\
\text { expression) }\end{array}$ & [63] \\
\hline & & MCF7 T47D & $\begin{array}{l}\downarrow \mathrm{EMT}(\uparrow E \text {-cadherin gene and } \\
\quad \text { protein expresssion) }\end{array}$ & [64] \\
\hline & \multirow{3}{*}{ TNBC } & \multirow{2}{*}{ MDA-MB-231 } & $\begin{array}{c}\uparrow \mathrm{EMT}(\uparrow \text { Snail, } \uparrow Z e b-2 \text { genes } \\
\text { expression) }\end{array}$ & [63] \\
\hline & & & $\begin{array}{l}\uparrow E M T \text { ( } \uparrow \text { Snail, } \downarrow \text { E-cadherin, } \\
\downarrow G K S 3 \beta \text { genes expression) }\end{array}$ & [57] \\
\hline & & MDA-MB-468 & $\begin{array}{c}\uparrow E M T(\uparrow N \text {-cadherin gene and } \\
\text { protein expression) }\end{array}$ & [64] \\
\hline \multirow{2}{*}{ miRNA } & Luminal & MCF7 & $\uparrow \mathrm{miR}-34 \mathrm{a}, \uparrow \mathrm{miR}-520 \mathrm{~h}$ expression & [56] \\
\hline & TNBC & MDA-MB-231 & $\uparrow \mathrm{miR}-34 \mathrm{a}, \uparrow \mathrm{miR}-520 \mathrm{~h}$ expression & [56] \\
\hline ER receptor status & TNBC & MDA-MB-231 & $\begin{array}{c}\uparrow E R \alpha, \uparrow F o x A 1 \text { genes and proteins } \\
\text { expression }\end{array}$ & [66] \\
\hline $\begin{array}{l}\text { Metabolic } \\
\text { pathways }\end{array}$ & Luminal & MCF7 & $\begin{array}{c}\uparrow \text { furfural expression, alteration in } \\
\text { alanine, taurine and hypotaurine } \\
\text { metabolism }\end{array}$ & [67] \\
\hline
\end{tabular}

$\uparrow$-increase, $\downarrow$-decrease.

\subsection{VPA Regulates Migration and Epithelial-Mesenchymal Transition (EMT)}

Sodium valproate (VPA-derivative) at concentrations of $0.8-3.2 \mathrm{mM}$ inhibits migration of MDA-MB-231 TNBC cells in a dose-dependent manner by upregulation of nm23H1 gene expression [65]. Nm23 (non-metastatic clone 23), also known as ndpk (nucleoside diphosphate kinase), is a metastasis suppressor gene locating on codon 21.3 of the long arm of chromosome 17. The $\mathrm{Nm} 23 \mathrm{H} 1$ protein acts as an upstream regulator that modulates downstream metastasis-related genes, which results in tumor metastasis inhibition. Overexpression of $\mathrm{nm} 23 \mathrm{H} 1$ gene decreases proliferation, invasion, and metastasis of cancer cells, probably mediated by $\mathrm{nm} 23 \mathrm{~h} 1$ regulation by the HDACs. It has been reported, that silencing of $\mathrm{nm} 23 \mathrm{H} 1$ resulted in an increased in rac (Rac family small GTPase 1) gene expression and, in consequence, in the invasive ability of TNBC cells. Overexpression of $\mathrm{nm} 23 \mathrm{H} 1$ can be a promising prognostic indicator linked with longer overall survival of patients harboring various types of cancers, including BC. However, the mechanism by which Nm23H1 participates in tumor metastasis is not fully understood $[65,68,69]$.

Besides inhibition of cell migration, VPA affects the epithelial to mesenchymal transition (EMT). EMT is an important process of transdifferentiation in solid cancers progression and the development of metastasis. During EMT polarized, immotile epithelial cells are transformed into migratory mesenchymal-like cells prone to migration, metastasis formation, drug resistance, and $\mathrm{BC}$ stemness features development [70-73]. Numerous signaling pathways are involved in the EMT process, including: cadherin [74], notch [75], transforming growth factor- $\beta$ (TGF- $\beta$ ) [76], matrix metalloproteinases [77], urokinase plasminogen activator [78] and WNT/beta-catenin [79,80] pathways [70]. However, understanding of the crosstalk of multisignaling pathways as well as assemblies of key transcription factors involved in the EMT process remains incomplete [10,70]. It has been demonstrated that VPA in concentration $1 \mathrm{mM}$ does not affect cancer cell proliferation, whereas significantly increases the migration and induces EMT-like properties of MCF7 luminal and MDAMB-231 TNBC cells via upregulation of Snail and Zeb1 transcription factors expression. Moreover, knockdown of Snail and Zeb1 attenuate VPA induced cell migration and EMT process. VPA increases the Snail protein stability through suppression of its phosphorylation at serine 11 (Ser 11). VPA also increases the transcription and promoter activity of Zeb1 via HDAC2-dependent manner. HDAC2 overexpression blocks VPA-induced Zeb1 
expression [63]. In line with these findings, another research group confirmed that VPA induces cell migration and EMT process in TNBC cells through a significant increase of Snail expression and downregulation of E-cadherin and GKS3 $\beta$ levels. Interestingly, the levels of $\beta$-catenin and AKT were reduced after VPA treatment, suggesting that AKT $/$ GSK3 $\beta / \beta$ catenin signaling pathway does not mediate EMT activation [57]. Increased migration and EMT are usually associated with the worst prognosis tumors; thus, the use of VPA in monotherapy of metastatic BC may be limited. The EMT is a process characteristic of solid tumors, therefore the low therapeutic effectiveness of HDIs in this type of neoplasms may be associated with the activation of EMT process.

Changes in the expression of cadherins, so-called cadherin switches, are used very often to monitor the EMT process in development and tumor progression, in particular migration and invasion potential. It has been demonstrated that VPA inhibits the proliferation and migration in a time- and dose-dependent fashion, regardless of the $\mathrm{BC}$ cell type. However, $\mathrm{BC}$ cells with the more mesenchymal phenotype (MDA-MB-468) were found to overexpress $\mathrm{N}$-cadherin, whereas BC lines with an epithelial phenotype (T47D, MCF7) responded to HDI treatment through a significant increase in E-cadherin expression. Therefore, the authors conclude that HDI induction or reversal of EMT is not a universal mechanism, yet inhibition of cell migration is, and thus EMT should not be considered as the only measurement for tumor aggressiveness [64]. Taking into account the very divergent results regarding the influence of VPA on the EMT process this phenomenon should be thoroughly re-examined using the entire panel of BC cell lines and in vivo models (Table 3).

\subsection{VPA Affects microRNAs (miRNAs) Expression}

MicroRNAs (miRNAs) are small RNAs that suppress gene expression through their interaction with 3'untranslated region in specific target mRNAs. Non-coding RNAs (ncRNAs), including miRNAs exert critical function in the regulation of cellular processes that are involved in the EMT, as a result, some miRNAs impact cancer stemness and drug resistance. Therefore, understanding the relationship between EMT and miRNAs is beneficial to both basic research and clinical treatment [81-84]. The impact of VPA on miR-34a [85], miR-520h [81], and their target gene HDAC1 expression, as well as their involvement in the induction of apoptosis in MCF-7 and MDA-MB-231 BC cell lines, were evaluated. miRNA34a is a well-described EMT-inhibiting miRNA [85]. In the beginning, possible target genes of miR-34a and miR-520h as well as their role in apoptosis regulation were investigated using bioinformatics analyses. Potential targets of hsa-miR-34a-5p and hsa-miR-520h-5p were in silico evaluated using predictive databases, then, a functional enrichment analysis was performed with the resulting target genes, to determine genes involved in apoptosis pathway and expressed in BC tissue. Furthermore, the interactions of the potential target genes with each other as well as with hsa-miR-34a-5p and hsa-miR-520h-5p were evaluated using STRING where 56 potential interactions between the above-mentioned miRNAs and apoptosis genes were described. It has been demonstrated that VPA increases the expression of miR-34a and miR-520h and decreases HDAC1 expression in MCF-7 cells. In turn, VPA decreased the expression of these miRNAs and increased the HDAC1 expression in MDA-MB-231 BC cells. Similarly like in MDA-MB-231 BC cells, in cancer tissue the expression of miR-34a and miR-520h significantly decreased, while the expression of HDAC1 increased after VPA treatment in vivo. This raises the possibility that VPA differently regulates the expression of the same genes, depending on BC cancer type or their molecular profiling (Table 3) [56].

Changes in the miRNA level were observed after VPA treatment also in pancreatic [86], colon [87] or thymic carcinomas [88], as well as acute myeloid leukemia [89]. VPA treatment induced expression of ErbB family members-targeting microRNAs (miR-133a, miR-133b, $\mathrm{miR}-125 \mathrm{a}, \mathrm{miR}-125 \mathrm{~b}$, and miR-205) in pancreatic cancer cells without altering mRNAs levels of EGFR, ErbB2, and ErbB3 [86]. A role for these miRNAs has been demonstrated in BC. miR-133 targets YES1 proto-oncogene and inhibits the growth of TNBC cells [90]. MiR-205 suppresses the malignant behaviors of BC cells by targeting CLDN11 via modulation of 
the EMT [91]. It has been also demonstrated that the expression of the tumor-suppressing microRNA-125b decreased in samples of BC expressing HER2 and ER, and in TNBC [92]. In turn, treating colon cancer cells with VPA reduces the levels of precursor-miR17-92a and mature miR-92a, as well as c-Myc [87]. The upregulation of miR-92a-3p was detected in tamoxifen-resistant BC cells, suggesting that lower level of miR-92a-3p could effectively improve the therapy with this drug [93]. It was also found that VPA treatment of TC1889 cells (thymic carcinoma) led to miR-145-5p up-regulation and concomitant down-regulation of miR-145-5p target genes and exhibited antitumor effects, including cell cycle arrest and the reduction of cell viability, migration capability and, colony-forming ability [88]. miR-145-5p suppresses BC progression by inhibition of (sex-determining region Y)-box 2 (SOX2) [94], a transcription factor that is essential for maintaining self-renewal and pluripotency in BC cells [95]. VPA treatment downregulated expression of CHEK1, RAD51 as well as TYMS genes, which were identified as putative targets of miR-15a and miR16 in acute myeloid leukemia [89]. It was demonstrated that miR-15a/miR-16 induces mitochondrial-dependent apoptosis in BC cells by suppressing oncogene BMI1 [96]. The expression and role of individual mRNAs depend on the type of tumor; thus the potential effect of VPA on individual miRNAs requires further research.

\subsection{VPA and Estrogen Receptor Status}

It has been demonstrated that VPA affects not only cell migration, proliferation, and cancer cell survival, but also the expression and activation of hormone receptors in $\mathrm{BC}$ cells observed in the pre-clinical and clinical studies [97]. Therefore, VPA can be valuable drugs in BC therapy where ER receptor is silenced by epigenetic modifications. It has been reported that ER receptor can be indirectly activated by sub-therapeutic doses of VPA. Sub-therapeutic concentrations of VPA $(100 \mu \mathrm{M})$ can mimic estrogen and induce growth in an estrogen-depleted medium. This effect was abolished by adding an estrogen receptor antagonist. Nonetheless, therapeutic doses of VPA act via mechanisms unrelated to the stimulation of estrogen [98]. Interestingly, MDA-MB-231 ER-negative BC cells re-activate ER receptor expression and function after VPA treatment. It has been reported that VPA induced mRNA and protein expression of ER-alpha, while did not modify the level of ER-beta. Consequently, VPA increased expression of the ER-related transcription factor FoxA1, induced inhibitory effect of tamoxifen on cell growth, and caused estradiol-induced up-regulation of estrogen-regulated genes (e.g., pS2, progesterone receptor). Summarizing, VPA inducing ER-alpha and FoxA1, conferred to MDA-MB 231 cells an estrogen-sensitive phenotype, restoring their sensitivity to anti-estrogen therapy (Table 3) [66].

\subsection{VPA Affects Metabolic Pathways}

Metabolomics is a post-genomic research area comprising different analytical methods for small molecules analysis [99]. Metabolomics is a promising strategy to explain the pathogenesis of cancer and identify new targets for cancer diagnosis and therapy [67]. The effect of VPA on metabolites and metabolic pathways in BC cells was determined. Metabolomic analysis based on UPLC-MS/MS allowed for the identification of 3137 differential metabolites of VPA in MCF-7 cells and 2472 metabolites in MDA-MB-231 BC cells after VPA treatment. VPA particularly affected the beta-alanine, taurine, and hypotaurine metabolism pathways. Expression of furfural was up-regulated after VPA treatment in both $\mathrm{BC}$ cell lines. All these findings can contribute to the identification of new targets for BC treatment (Table 3) [67].

\section{5. "Valproic Acid et al." and Breast Cancer}

Despite the significant progress in the development of novel therapeutic options, standard chemotherapy of cancers still does not bring satisfactory results $[58,100,101]$. Chemotherapy with the use of standard cytostatics or their derivatives is limited due to many adverse effects, high toxicity to normal cells, or the occurrence of chemotolerance [102]. Therefore, combinations of established anticancer chemotherapeutics and new 
active agents with different mechanisms of action are being tested to increase the effectiveness of the therapy and improve clinical outcomes of oncological patients $[58,103]$. New active compounds approved for the treatment of BC, which effectively and selectively eliminate $\mathrm{BC}$ cells, and additionally enhance anticancer properties of currently used chemotherapeutics without destroying healthy tissue, are of great importance $[11,59]$. It has been demonstrated that new active agents not only reduce the effective doses of chemotherapeutic drugs but also sensitize cancer cells to standard cytostatics, increase the combined therapeutic activity of both active compounds and limit cytotoxic effect in relation to human normal cells through lowering the therapeutic doses of standard cytostatics by partially replacing them with new less toxic active agents. Additionally, combined therapy with new active agents can diminish multidrug-resistance (MDR) of currently used chemotherapeutic regimens [103]. In this context, many natural [103-106] and synthetic chemical compounds, including HDIs [11,58,59], have been identified and have become an interesting class of active agents for combined anti-cancer therapy.

Cisplatin (CDDP) or cis-diamminedichloroplatinum (II) is a well-known chemotherapeutic drug widely used in the therapy of numerous human cancers including lung, head and neck, bladder, ovarian, testicular, or TNBC. The mechanism of action of CDDP is linked to its ability to crosslink with the purine bases on the DNA, interfering with DNA repair mechanisms, causing DNA damage, and subsequently inducing apoptosis pathways in cancer cells. However, due to drug resistance and numerous adverse effects such as kidney insufficiency, gastrointestinal disorders, allergic reactions, hemorrhage, decreased immunity to infections, and hearing loss, the use of CDDP is limited [107]. The combination of VPA and CDDP resulted in the induction of apoptosis and cell cycle arrest in G1 phase in receptor-positive as well as TNBC cell lines in comparison to CDDP-monotherapy. CDDP with VPA applied together at a fixed-ratio of 1:1 exerted additive or additive with the tendency towards synergy interactions in the viability of MCF7 and T47D cells, respectively. In contrast, antagonistic (sub-additive) interaction was observed for the combination of CDDP with VPA in MDA-MB-231 TNBC cell line [59]. Interestingly, combined treatment of VPA and CDDP in MDA-MB-231 BC cells with the altered (increased or decreased) activity of Notch1 receptor yielded additive interaction. Therefore, VPA might be considered as potential therapeutic agents in combination therapy with CDDP against TNBC with altered Notch1 activity (Table 4) [58].

Table 4. Mechanism of action of valproic acid (VPA) and other anti-cancer drugs in combination in in vitro and in vivo breast cancer (BC) pre-clinical setting (CDDP-cisplatin, CDK-cyclin-dependent kinase, DXR-doxorubicin, 5-FU-5-fluorouracil, HER2-human epidermal growth factor receptor 2, N/A-not analyzed, PARP-poly (ADP-ribose) polymerase 1, TNBC-triplenegative breast cancer).

\begin{tabular}{|c|c|c|c|c|c|}
\hline $\begin{array}{l}\text { Drug-Drug } \\
\text { Combination }\end{array}$ & BC-Subtype & Cell Line & Mechanism of Action & $\begin{array}{c}\text { Type of } \\
\text { Pramacological } \\
\text { Interaction }\end{array}$ & References \\
\hline \multirow{4}{*}{$\mathrm{VPA}+\mathrm{CDDP}$} & \multirow[b]{2}{*}{ Luminal } & MCF7 & \multirow[b]{2}{*}{$\begin{array}{c}\uparrow \text { apoptosis, } \downarrow \text { cell viability, } \\
\text { cell cycle arrest }\end{array}$} & additivity & {$[59]$} \\
\hline & & T47D & & $\begin{array}{l}\text { additivity with } \\
\text { tendency towards } \\
\text { synergism }\end{array}$ & [59] \\
\hline & \multirow[b]{2}{*}{ TNBC } & MDA-MB-231 & $\begin{array}{c}\uparrow \text { apoptosis, } \downarrow \text { cell viability, } \\
\text { cell cycle arrest }\end{array}$ & antagonism & [59] \\
\hline & & $\begin{array}{c}\text { MDA-MB-231 with } \\
\text { decreased and increased } \\
\text { Notch1 activity }\end{array}$ & $\downarrow$ cell viability & additivity & [58] \\
\hline $\mathrm{VPA}+5-\mathrm{FU}$ & TNBC & MDA-MB-468 & $\begin{array}{l}\text { sensitization of BC cells } \\
\text { insensitive to } 5-\mathrm{FU}\end{array}$ & $\mathrm{N} / \mathrm{A}$ & {$[108]$} \\
\hline VPA+capecitabine & $\begin{array}{c}\text { Luminal, } \\
\text { HER2-overexpressed, } \\
\text { TNBC }\end{array}$ & $\begin{array}{l}\text { MCF7, SKBR3, } \\
\text { MDA-MB-231, } \\
\text { MDA-MB-468 }\end{array}$ & $\begin{array}{c}\downarrow \text { proliferation, } \\
\uparrow \text { apoptosis, } \uparrow \text { thymidine } \\
\text { phosphorylase gene and } \\
\text { protein expression }\end{array}$ & synergism, additivity & {$[109]$} \\
\hline
\end{tabular}


Table 4. Cont.

\begin{tabular}{|c|c|c|c|c|c|}
\hline $\begin{array}{l}\text { Drug-Drug } \\
\text { Combination }\end{array}$ & BC-Subtype & Cell Line & Mechanism of Action & $\begin{array}{c}\text { Type of } \\
\text { Pramacological } \\
\text { Interaction }\end{array}$ & References \\
\hline VPA+camptothecin & Luminal & MCF7 & $\begin{array}{l}\uparrow \text { apoptosis }(\downarrow \mathrm{BcL}-\mathrm{xl} \\
\text { protein espression) }\end{array}$ & $\begin{array}{l}\text { synergism (more } \\
\text { than additivity) }\end{array}$ & {$[110]$} \\
\hline VPA+DXR & TNBC & Hs578T & $\begin{array}{c}\downarrow \text { viability, } \uparrow \text { cytotoxicity, } \\
\uparrow \text { apoptosis, } \uparrow C x 43 \\
\text { protein expression }\end{array}$ & $\mathrm{N} / \mathrm{A}$ & {$[111]$} \\
\hline $\begin{array}{c}\text { VPA+AZD2461 } \\
\text { (PARP1 inhibitor) }\end{array}$ & Luminal & MCF7 & $\downarrow$ viability & mild antagonism & {$[112]$} \\
\hline $\begin{array}{l}\text { VPA+PD-033299 } \\
\text { (CDK inhibitor) }\end{array}$ & $\begin{array}{c}\text { Luminal, } \\
\text { HER2-overexpressed, } \\
\text { TNBC }\end{array}$ & $\begin{array}{c}\text { Panel of BC cells (MCF7, } \\
\text { T47D, BT474, } \\
\text { MDA-MB-361, SKBR3, } \\
\text { HCC1143, HCC38, } \\
\text { HCC1806, BT483, BT549, } \\
\text { MDA-MB-435, } \\
\text { MDA-MB-453,) and 3D } \\
\text { cultures from pleural } \\
\text { effusion of patients }\end{array}$ & $\begin{array}{l}\text { } \text { apoptosis, cell cycle } \\
\text { arrest, overexpression of } \\
\text { CDKN1C gene }\end{array}$ & synergism & [113] \\
\hline
\end{tabular}

5-fluorouracil (5-FU) is one of the oldest chemotherapeutic drugs routinely used in single or combined modalities with other chemotherapeutic agents in the therapy of a variety of solid tumors, including BC. Mechanism of action of 5-FU has been attributed to the production of cytotoxic metabolites that are incorporated into DNA and RNA, and inhibiting thymidylate synthase, finally leading to apoptosis and cell cycle arrest in cancer cells [114]. Resistance to 5-FU is a serious clinical problem in cancer therapy, and overcoming it is a challenge for chemotherapy. HDIs can overcome resistance to various anti-cancer drugs in vitro. It has been reported that VPA increases the sensitivity of MDAMB-468 TNBC cells to 5-FU in 5-FU sensitive and 5-FU resistant BC cells (Table 4) [108].

Capecitabine is an oral prodrug of $\mathrm{FU}$, which is approved for the treatment of metastatic BC in different settings [115]. The combined therapy of VPA and capecitabine resulted in synergistic or additive antiproliferative and pro-apoptotic effects in BC cells in vitro and in vivo. It has been demonstrated that low anticonvulsant dosage of VPA induces the time- and dose-dependent up-regulation of thymidine phosphorylase (TP) gene and its protein expression in $\mathrm{BC}$ cells, however, TP level remains unchanged in the non-tumorigenic MCF-10A cells. TP is a key enzyme requires for its conversion of FU to 5-FU in tumors. HDAC3 was the main isoform whose inhibition was involved in the modulation of TP activity. Thereby, the combination of VPA and capecitabine could be regarded as an innovative anti-cancer strategy for the therapy of BC (Table 4) $[8,109]$.

Camptothecin is a naturally occurring alkaloid derived from the Camptotheca acuminate. Camptothecin forms a stable ternary complex, prevents normal DNA re-ligation, and causes the complex to collide with the replication fork, leading to a DNA double-strand break $[116,117]$. It has also been demonstrated that VPA and camptothecin applied together induce caspase-dependent apoptosis through modulation of anti- and pro-apoptotic gene expression and loss of the mitochondrial membrane potential in MCF7 BC cells, whereas neither compound alone could efficiently induce apoptosis. It has been demonstrated that Bcl-xL expression was induced in MCF-7 BC cells treated with camptothecin alone, in contrast to cells treated with camptothecin and VPA together. Induction of apoptosis was completely suppressed by the ectopic of Bcl-xL overexpression in MCF-7 cells. Camptothecin and Bcl-xL inactivation with using siRNA or BH3 mimetic caused efficient induction of apoptosis in these cells. The cytotoxic effect of camptothecin in combination with VPA was more than additive in MCF-7 BC cells, therefore simultaneous administration of VPA and camptothecin can be a useful strategy for therapy of BC (Table 4) [110].

Doxorubicin (DXR) is a member of the anthracycline family and is currently the most effective chemotherapeutic drug used in the treatment of early and advanced breast 
cancer. Unfortunately, it has been demonstrated that DXR can induce drug resistance which limits the effectiveness of the agent in single-drug treatment regimes. However, the exact mechanisms of drug resistance are still poorly understood [118,119]. Sodium valproate significantly enhanced the cytotoxicity of DXR and stimulated apoptosis induced by DXR in vitro. Exposure to sodium valproate and DXR in combination resulted in significantly increased early and late cell apoptosis rate and lowered cell viability compared with doxorubicin treatment alone. Moreover, western blotting analysis demonstrated that sodium valproate increased connexin 43 (Cx43) protein expression in Hs578T BC cells [120]. Cx43 is a prominent gap junction protein within the normal human breast tissue. Cx43 plays a tumor-suppressive role in primary tumors (Table 4) [111].

Poly (ADP-ribose) polymerase 1 (PARP1) and cyclin-dependent kinase (CDK) inhibitors. PARP1 inhibitors are newly developed anticancer active agents which target cells with defects in the homologous recombination (HR) pathway. Newly developed PARP1 inhibitor AZD2461 and VPA can effectively reduce the growth of MCF-7 BC cells with no fundamental DNA repair defect. VPA and AZD2461 applied together decreased cell viability of MCF-7 cells, where $\mathrm{IC}_{50}$ values for VPA and AZD2461 were $4.89 \mathrm{mM}$ and $42.83 \mu \mathrm{M}$, respectively after $48 \mathrm{~h}$ of treatment with active agents. Also, the trypan blue exclusion assay results showed a time- and dose-dependent decrease in cell viability in luminal BC cells after treatment with both compounds. Unfortunately, combination analysis showed a mild antagonism between VPA and AZD2461 while $\gamma$-H2AX levels were found not to be significantly increased in MCF-7 cells treated with VPA and AZD2461 together compared to each compound alone [112]. However, it has been reported that HDAC (VPA) and cyclin-dependent kinase (CDK) inhibitors (PD-033299) show synergistic interaction in BC cells and 3D cultures from pleural effusions of patients (Table 4) [113].

\section{Valproic Acid Derivatives and Drug Carriers}

VPA derivatives are promising antiproliferative agents targeting the HDAC8. Unfortunately, most of these compounds are poorly soluble in water. Therefore, G4 PAMAM, four generations of polyamidoamine dendrimers, were used to improve VPA derivatives' water solubility. It has been demonstrated that G4 PAMAM dendrimers are capable of transporting weakly water-soluble aryl-VPA derivate compounds to increase their cytotoxicity against BC cell lines. VPA/CF-G4 PAMAM dendrimer complex shows anti-proliferative activity against MCF-7 and 3T3-L1, as well as MDA-MB-231 BC cells in the micro- and millimolar concentrations, respectively. Molecular docking and molecular dynamics simulations as well as HPLC-UV /VIS, MALDI-TOF, 1H NMR, and atomic force microscopy were used to evaluate the affinity of VPA, and its derivatives on G4 PAMAM, and then to establish the formation of the drug-G4 PAMAM complexes. HPLC UV/VIS experiments demonstrated an increase in the drug water solubility which was proportional to the G4 PAMAM amount [121]. Thus, chemical modification of VPA derivatives together with carrier development could provide a new treatment concept in the future.

\section{Clinical Trials}

Several HDIs are now being tested in BC patients in different clinical trials ranging from early phase I to randomized phase III either as single agents or in combination with approved cytostatic agents [122-127]. Despite the proven activity and high effectiveness of the use of some HDIs in hematologic malignancies [42-45], the single-agent activity seems more limited in solid tumors. Somehow, results from certain clinical trials are promising, especially those that employed VPA in combination with other chemotherapeutic drugs. Combination of VPA and epirubicin or FEC100 (5-fluorouracil, epirubicin, and cyclophosphamide), an approved regimen for BC patients, were determined [128,129]. The I phase of the study enrolled 44 patients with different solid tumors to determine the safety, toxicity, and maximum-tolerated dose of a sequence-specific combination of VPA and epirubicin. Patients were treated with increasing doses of VPA (days 1-3) followed by epirubicin (day 3) in 3-week cycles. The maximum-tolerated and recommended doses for II phase were 
determined (VPA $140 \mathrm{mg} / \mathrm{kg} / \mathrm{d}$ for $48 \mathrm{~h}$ followed by epirubicin $100 \mathrm{mg} / \mathrm{m}^{2}$ ). Interestingly, sustained plasma concentrations of VPA exceeding those required for in vitro synergy were achieved with acceptable toxicity. Moreover, anticancer activity of VPA and epirubicin was observed in patients with anthracycline-resistant tumors [128]. In the II phase dose expansion enrolled 15 patients with locally advanced (IIIC) or metastatic (IV) BC (14 evaluable for response). Patients in the dose-expansion group were treated with a $120 \mathrm{mg} / \mathrm{kg} /$ day VPA loading dose followed by $60 \mathrm{mg} / \mathrm{kg}$ given every $12 \mathrm{~h}$ for 5 doses followed by FEC100. At dose-expansion, 9 of $14(64 \%)$ evaluable patients had an objective response. In the trial, it has been demonstrated that a combination of VPA and FEC100 has an acceptable toxicity profile and antitumor efficacy [129]. In addition to VPA, its derivatives have been tested in clinical trials. The biological and clinical efficacy as well as the safety of magnesium valproate and hydralazine (methyltransferase inhibitor) in combination with doxorubicin cyclophosphamide in the neoadjuvant treatment of locally advanced $\mathrm{BC}$, were determined. BC patients were treated with $182 \mathrm{mg}$ or $83 \mathrm{mg}$ of hydralazine for rapidor slow-acetylators, respectively; and $30 \mathrm{mg} / \mathrm{kg}$ of magnesium valproate, starting from the day-7 until chemotherapy ended, the latter consisting of four cycles of doxorubicin $60 \mathrm{mg} / \mathrm{m}^{2}$ and cyclophosphamide $600 \mathrm{mg} / \mathrm{m}^{2}$ every 21 days. Needle biopsies were taken from primary tumors at diagnosis and day 8 of treatment with valproate and hydralazine. Regarding the safety of cytotoxic chemotherapy-associated magnesium valproate and hydralazine, this treatment was well-tolerated. Drowsiness in the majority of patients was the toxicity that could be attributed to the experimental therapy with valproate, however, it was not interfering with patient functioning in daily living. Interestingly, magnesium valproate and hydralazine in combination up- and down-regulated 89 and 1091 genes at least 3-fold, respectively. The results of this study demonstrate that therapy with valproate and hydralazine is safe, that it achieves the molecular changes expected from the use of HDI and demethylating agents, and appear to increase the efficacy of conventional cytostatic drugs [130]. M.D. Anderson Cancer Center is currently recruiting participants for the phase I clinical trial to determine the side effects and the maximum tolerated doses (MTDs) and dose-limiting toxicities (DLTs) of bevacizumab and temsirolimus alone or in combination with VPA or cetuximab in patients with advanced or metastatic malignancy, including BC (III and IV stages). In the clinical trial patients receive temsirolimus intravenously (i.v.) over 30-60 min on days 1, 8, 15, and 22, bevacizumab i.v. over 30-90 min on days 1 and 15, and VPA orally (p.o.) daily on days 1-7 and 15-21. The purpose of the study is the preliminary assessment of the anti-tumor efficacy of each combination, assessment of the pharmacokinetics, pharmacodynamic markers of target inhibition, and correlates of response [131].

\section{Discussion}

$\mathrm{BC}$ is one of the leading causes of cancer-related death among women worldwide. A significant challenge in treating $\mathrm{BC}$ is the limited array of therapeutic options and the rapid development of resistance against currently used agents, especially in TNBC, the most aggressive subtype of $\mathrm{BC}$ [97]. The idea of treating $\mathrm{BC}$ patients with active agents able to re-establish expression of tumor suppressor genes silenced by epigenetic mechanisms is currently being tested [132]. Up-regulated HDAC activity is associated with a closed chromatin assembly and subsequent gene repression, forming a characteristic feature of malignantly transformed cells $[133,134]$. Histone acetylation prevents chromatin condensation as well as makes promoters and other control elements of chromatin more accessible to different transcription factors, and thus seems to be the most important mechanism in HDIs anticancer action [135]. HDIs as the epigenetic modifiers have pleiotropic effects on many biological processes such as cancer cell growth arrest, proliferation, differentiation, angiogenesis, invasion, metastasis or immunogenicity [135]. VPA is a clinically available HDI that notably increases apoptosis, induces cell cycle arrest, and abolishes drug resistance in $\mathrm{BC}$ cells in vitro as well as decreases tumor growth and metastases in animal models [135]. However, divergent data on the effects of VPA on different signaling 
pathways, including the EMT process or miRNA pathways limit the use of this compound as a single agent in the therapy of BC, although VPA is currently still prescribed worldwide as a well-tolerated, relatively safe and effective anticonvulsant and mood stabilizer. Even though other HDIs have demonstrated more promising antitumor effects, VPA was investigated for anti-cancer activity based on its low toxicity profile and availability. It has been shown excellent tolerability of VPA within the serum range of 50-100 $\mu \mathrm{g} / \mathrm{mL}$ based on experience from its use as an antiepileptic agent [136]. VPA was rapidly absorbed after oral administration, with peak serum levels occurring approximately $1-4 \mathrm{~h}$ after a single oral dose [135]. Due to the fact, that VPA has been used in clinical practice in nontoxic therapeutic concentrations in many seizure types and syndromes, and remains a mainstay for treatment of epilepsy of all age groups except for infants, as well as mania in bipolar disorders, migraine prophylaxys, neuropathic pain and schizophrenia, for more than four decades, its pharmacokinetic profile, side effects and toxicity are thus well documented [135]. Moreover, therapy with VPA is widespread, relatively cheap, and available. Since VPA, as a psychoneurological drug, crossing the blood-brain barrier, it could also effectively eliminate metastatic BC cells in the brain of patients. There is currently no effective therapy for treating metastatic TNBC in the brain. The diagnosis of an oncological disease may cause a serious psychological crisis, and the use of VPA in the treatment of $\mathrm{BC}$ could simultaneously reduce the symptoms of neuropsychiatric diseases. VPA is generally well tolerated by patients. However, neurological side effects such as dizziness, sedation, and tremor as well as mild gastrointestinal toxicities usually occur early during treatment. Fatal hepatotoxicity is very rare and mainly occurs in children aged less than 2 years who are treated with multiple drugs [137]. VPA is also a known human teratogen and its prescription during pregnancy (especially in the first trimester) may cause multiple birth defects that are overall designated as fetal valproate syndrome. The major congenital abnormalities are neural tube defects, facial dysmorphism, growth retardation, delay in postnatal cognitive development, and autism [135]. Despite the side effects of VPA, especially in pregnant women, clinical trials are still ongoing for its potential application in the treatment of several types of cancers, including solid and non-solid tumors [138]. While VPA administered alone demonstrated an anti-cancer effect in the pre-clinical setting, little improvement was observed with VPA in monotherapy in the clinical setting. These findings suggest that VPA needs to be combined with hormonal therapy agents or traditional chemotherapy agents in the $\mathrm{BC}$ setting in the future. The promising pre-clinical data suggest that VPA can be repurposed as an adjunctive agent in combination with many cytotoxic, hormonal, and immunotherapeutic agents for the treatment of BC [97]. The effect of VPA in monotherapy on induction of apoptosis, inhibition of the cell cycle, EMT or miRNA pathways do not differ significantly between the histological subtypes of BC. However, it has been demonstrated that HER2-overexpressed BC cells are more sensitive to VPA than HER2-negative. It is known that the anti-proliferative mechanism of VPA in BC cells is related to their HER2-expression status. Therefore, VPA may synergize with drugs used in the therapy of HER2-overexpressed BC, like anti-HER2 monoclonal antibodies or anthracycline and taxane-based neoadjuvant chemotherapy. Interestingly, a different therapeutic effect was observed in the VPA-combined therapy depending on the type of BC. It has been demonstrated that the anticancer effect of VPA in combination with other active agents, is highly cell-type specific. Additivity or additivity with a tendency towards synergism was demonstrated between VPA and CDDP in luminal BC cells, while antagonism was evidenced in TNBC cells between the same drug combination. Interestingly, changes in Notch1 activity in MDA-MB-231 TNBC cells caused additive interaction. Therefore, the therapy with VPA and CDDP can be a promising regimen in patients with the most aggressive type of BC-TNBC with increased Notch1 activity. Synergistic type of pharmacological interaction was also demonstrated between VPA and capecitabine or PD-033299 (CDK inhibitor) in luminal, HER2-overexpressed, and TNBC cells as well as with camptothecine in luminal BC cells. In contrast, mild antagonism was evidenced in luminal BC cells treated with VPA in combination with AZD2461 (PARP1 inhibitor). 
However, further investigations are warranted to evaluate the efficacy and to provide optimal treatment.

\section{Conclusions}

Despite significant progress in the therapy of $\mathrm{BC}$ patients, serious side effects, as well as high toxicity of standard chemotherapeutics to normal cells limit the effectiveness of the therapy. Moreover, the existence of de novo drug resistance (tumor does not respond to treatment since the beginning of therapy) or acquired resistance (response to the drug disappears over time) support the failure of standard therapies and do not bring satisfactory results [139-141]. Thus, a new generation of cytostatics effective in the treatment of BC is being sought, the use of which will not only reduce the doses of standard chemotherapeutics but also eliminate the phenomenon of drug resistance. Clinical trials investigating new targeted drugs as well as therapeutic combinations with their use have led to significant advances in BC therapy [7]. Epigenetic regulation of histone and non-histone proteins may be a novel approach and hold significant progress for the successful treatment of BC. HDIs are a promising class of anti-neoplastic agents that induce differentiation and apoptosis in many types of cancer cells, including breast carcinoma cells [142]. VPA is a clinically available HDI that notably inhibits migration, increases apoptosis, cell cycle arrest, and abolishes drug resistance [108] in BC cells. Unfortunately, the $\mathrm{IC}_{50}$ doses of VPA are relatively high compared to other HDIs in in vitro studies [59]. Moreover, divergent data on the effects of VPA on different signaling pathways, including the EMT process or miRNA pathways limit the use of this compound in monotherapy of BC. Combined therapy with the use of VPA and standard cytostatic drugs to reduce the doses of VPA and limit the adverse effects caused by standard chemotherapeutics seems to be a promising strategy in the future. Unfortunately, data on the VPA activity in combination with other anti-cancer drugs from the in vivo models is still not sufficient. Therefore, results obtained from in vitro studies should be thoroughly validated in in vivo models. Results from in vivo experiments might offer a rationale for clinical studies of a new combined therapy, to improve the clinical outcome of patients with BC.

Author Contributions: Conceptualization, A.W. and A.S.; methodology, A.W., M.H., E.O., W.K.-K.; software, A.W.; resources, A.W., M.H., E.O., W.K.-K.; writing-original draft preparation, A.W., M.H., E.O., W.K.-K.; writing-review and editing, A.S.; visualization, A.W.; supervision, A.S.; project administration, A.W.; funding acquisition, A.W., M.H., A.S. All authors have read and agreed to the published version of the manuscript.

Funding: This research was funded by Medical University of Lublin, grant number DS440/2020 and DS440/2021-2022; The Iwanowska Programme, The Polish National Agency for Academic Ex-change, grant numbers PPN/IWA/2018/1/00005 and PPN/IWA/2019/1/00160.

Acknowledgments: The authors thank Agnieszka Styczynska for the editorial assistance and proof readings. All figures were created with www.biorender.com (accessed on 25 April 2021).

Conflicts of Interest: The authors declare no conflict of interest.

\section{References}

1. Bray, F.; Ferlay, J.; Soerjomataram, I.; Siegel, R.L.; Torre, L.A.; Jemal, A. Global cancer statistics 2018: GLOBOCAN estimates of incidence and mortality worldwide for 36 cancers in 185 countries. CA Cancer J. Clin. 2018, 68, 394-424. [CrossRef] [PubMed]

2. Momenimovahed, Z.; Salehiniya, H. Epidemiological characteristics of and risk factors for breast cancer in the world. Breast Cancer Targets Ther. 2019, 11, 151-164. [CrossRef] [PubMed]

3. The Lancet GLOBOCAN 2018: Counting the toll of cancer. Lancet 2018, 392, 985. [CrossRef]

4. Ferlay, J.; Colombet, M.; Soerjomataram, I.; Mathers, C.; Parkin, D.M.; Piñeros, M.; Znaor, A.; Bray, F. Estimating the global cancer incidence and mortality in 2018: GLOBOCAN sources and methods. Int. J. Cancer 2019, 144, 1941-1953. [CrossRef] [PubMed]

5. Janni, W. Targeted Therapy of Breast Cancer. Oncol. Res. Treat. 2016, 39, 100-101. [CrossRef]

6. Nagini, S. Breast Cancer: Current Molecular Therapeutic Targets and New Players. Anticancer Agents Med. Chem. 2017, 17, 152-163. [CrossRef]

7. Cai, F.F.; Kohler, C.; Zhang, B.; Wang, M.H.; Chen, W.J.; Zhong, X.Y. Epigenetic therapy for breast cancer. Int. J. Mol. Sci. 2011, 12, 4465-4476. [CrossRef] 
8. Damaskos, C.; Valsami, S.; Kontos, M.; Spartalis, E.; Kalampokas, T.; Kalampokas, E.; Athanasiou, A.; Moris, D.; Daskalopoulou, A.; Davakis, S.; et al. Histone deacetylase inhibitors: An attractive therapeutic strategy against breast cancer. Anticancer Res. 2017, 37, 35-46. [CrossRef]

9. Gediya, P.; Parikh, P.K.; Vyas, V.K.; Ghate, M.D. Histone deacetylase 2: A potential therapeutic target for cancer and neurodegenerative disorders. Eur. J. Med. Chem. 2021, 216. [CrossRef] [PubMed]

10. Wawruszak, A.; Kalafut, J.; Okon, E.; Czapinski, J.; Halasa, M.; Przybyszewska, A.; Miziak, P.; Okla, K.; Rivero-Muller, A.; Stepulak, A. Histone deacetylase inhibitors and phenotypical transformation of cancer cells. Cancers 2019, 11, 148. [CrossRef]

11. Gumbarewicz, E.; Luszczki, J.J.; Wawruszak, A.; Dmoszynska-Graniczka, M.; Grabarska, A.J.; Jarzab, A.M.; Polberg, K.; Stepulak, A. Isobolographic analysis demonstrates additive effect of cisplatin and HDIs combined treatment augmenting their anti-cancer activity in lung cancer cell lines. Am. J. Cancer Res. 2016, 6, 2831-2845.

12. Dai, X.; Li, T.; Bai, Z.; Yang, Y.; Liu, X.; Zhan, J.; Shi, B. Breast cancer intrinsic subtype classification, clinical use and future trends. Am. J. Cancer Res. 2015, 5, 2929-2943. [PubMed]

13. Szymiczek, A.; Lone, A.; Akbari, M.R. Molecular intrinsic versus clinical subtyping in breast cancer: A comprehensive review. Clin. Genet. 2021, 99, 613-637. [CrossRef]

14. McDonald, E.S.; Clark, A.S.; Tchou, J.; Zhang, P.; Freedman, G.M. Clinical diagnosis and management of breast cancer. J. Nucl. Med. 2016, 57, 9S-16S. [CrossRef] [PubMed]

15. Bonacho, T.; Rodrigues, F.; Liberal, J. Immunohistochemistry for diagnosis and prognosis of breast cancer: A review. Biotech. Histochem. 2020, 95, 71-91. [CrossRef]

16. Cheang, M.C.U.; Chia, S.K.; Voduc, D.; Gao, D.; Leung, S.; Snider, J.; Watson, M.; Davies, S.; Bernard, P.S.; Parker, J.S.; et al. Ki67 index, HER2 status, and prognosis of patients with luminal B breast cancer. J. Natl. Cancer Inst. 2009, 101, 736-750. [CrossRef]

17. Smid, M.; Wang, Y.; Zhang, Y.; Sieuwerts, A.M.; Yu, J.; Klijn, J.G.M.; Foekens, J.A.; Martens, J.W.M. Subtypes of breast cancer show preferential site of relapse. Cancer Res. 2008, 68, 3108-3114. [CrossRef] [PubMed]

18. Gong, Y.; Liu, Y.R.; Ji, P.; Hu, X.; Shao, Z.M. Impact of molecular subtypes on metastatic breast cancer patients: A SEER population-based study. Sci. Rep. 2017, 7. [CrossRef]

19. Perou, C.M.; Sørile, T.; Eisen, M.B.; Van De Rijn, M.; Jeffrey, S.S.; Ress, C.A.; Pollack, J.R.; Ross, D.T.; Johnsen, H.; Akslen, L.A.; et al. Molecular portraits of human breast tumours. Nature 2000, 406, 747-752. [CrossRef] [PubMed]

20. Sørlie, T.; Perou, C.M.; Tibshirani, R.; Aas, T.; Geisler, S.; Johnsen, H.; Hastie, T.; Eisen, M.B.; Van De Rijn, M.; Jeffrey, S.S.; et al. Gene expression patterns of breast carcinomas distinguish tumor subclasses with clinical implications. Proc. Natl. Acad. Sci. USA 2001, 98, 10869-10874. [CrossRef]

21. Van Ramshorst, M.S.; van der Voort, A.; van Werkhoven, E.D.; Mandjes, I.A.; Kemper, I.; Dezentjé, V.O.; Oving, I.M.; Honkoop, A.H.; Tick, L.W.; van de Wouw, A.J.; et al. Neoadjuvant chemotherapy with or without anthracyclines in the presence of dual HER2 blockade for HER2-positive breast cancer (TRAIN-2): A multicentre, open-label, randomised, phase 3 trial. Lancet Oncol. 2018, 19, 1630-1640. [CrossRef]

22. Harbeck, N.; Gluz, O. Neoadjuvant therapy for triple negative and HER2-positive early breast cancer. Breast 2017, 34, S99-S103. [CrossRef]

23. Wuerstlein, R.; Harbeck, N. Neoadjuvant Therapy for HER2-positive Breast Cancer. Rev. Recent Clin. Trials 2017, 12, 81-92. [CrossRef] [PubMed]

24. Maximiano, S.; Magalhães, P.; Guerreiro, M.P.; Morgado, M. Trastuzumab in the Treatment of Breast Cancer. BioDrugs 2016, 30, 75-86. [CrossRef]

25. Cameron, D.; Piccart-Gebhart, M.J.; Gelber, R.D.; Procter, M.; Goldhirsch, A.; de Azambuja, E.; Castro, G.; Untch, M.; Smith, I.; Gianni, L.; et al. 11 years' follow-up of trastuzumab after adjuvant chemotherapy in HER2-positive early breast cancer: Final analysis of the HERceptin Adjuvant (HERA) trial. Lancet 2017, 389, 1195-1205. [CrossRef]

26. Drooger, J.C.; van Tinteren, H.; de Groot, S.M.; ten Tije, A.J.; de Graaf, H.; Portielje, J.E.A.; Jager, A.; Honkoop, A.; Linn, S.C.; Kroep, J.R.; et al. A randomized phase 2 study exploring the role of bevacizumab and a chemotherapy-free approach in HER2-positive metastatic breast cancer: The HAT study (BOOG 2008-2003), a Dutch Breast Cancer Research Group trial. Cancer 2016, 122, 2961-2970. [CrossRef] [PubMed]

27. Nagata, Y.; Lan, K.H.; Zhou, X.; Tan, M.; Esteva, F.J.; Sahin, A.A.; Klos, K.S.; Li, P.; Monia, B.P.; Nguyen, N.T.; et al. PTEN activation contributes to tumor inhibition by trastuzumab, and loss of PTEN predicts trastuzumab resistance in patients. Cancer Cell 2004, 6, 117-127. [CrossRef]

28. Marotti, J.D.; de Abreu, F.B.; Wells, W.A.; Tsongalis, G.J. Triple-Negative Breast Cancer: Next-Generation Sequencing for Target Identification. Am. J. Pathol. 2017, 187, 2133-2138. [CrossRef]

29. Jitariu, A.A.; Cîmpean, A.M.; Ribatti, D.; Raica, M. Triple negative breast cancer: The kiss of death. Oncotarget 2017, 8, 46652-46662. [CrossRef] [PubMed]

30. Jhan, J.R.; Andrechek, E.R. Triple-negative breast cancer and the potential for targeted therapy. Pharmacogenomics 2017, 18, 1595-1609. [CrossRef] [PubMed]

31. Chun, K.H.; Park, J.H.; Fan, S. Predicting and overcoming chemotherapeutic resistance in breast cancer. In Advances in Experimental Medicine and Biology; Springer LLC: New York, NY, USA, 2017; Volume 1026, pp. 59-104.

32. Reilly, D.O.; al Sendi, M.; Kelly, C.M. Overview of recent advances in metastatic triple negative breast cancer. World J. Clin. Oncol. 2021, 12, 164-182. [CrossRef] 
33. Mezi, S.; Botticelli, A.; Pomati, G.; Cerbelli, B.; Scagnoli, S.; Amirhassankhani, S.; D'amati, G.; Marchetti, P. Standard of care and promising new agents for the treatment of mesenchymal triple-negative breast cancer. Cancers 2021, 13, 1080. [CrossRef] [PubMed]

34. Loibl, S.; Poortmans, P.; Morrow, M.; Denkert, C.; Curigliano, G. Breast cancer. Lancet 2021. [CrossRef]

35. Liu, D.; Vadgama, J.; Wu, Y. Basal-like breast cancer with low TGF $\beta$ and high TNF $\alpha$ pathway activity is rich in activated memory CD4 T cells and has a good prognosis. Int. J. Biol. Sci. 2021, 17, 670-682. [CrossRef]

36. Cejalvo, J.M.; De Dueñas, E.M.; Galván, P.; García-Recio, S.; Gasión, O.B.; Paré, L.; Antolín, S.; Martinello, R.; Blancas, I.; Adamo, B.; et al. Intrinsic subtypes and gene expression profiles in primary and metastatic breast cancer. Cancer Res. 2017, 77, $2213-2221$. [CrossRef] [PubMed]

37. Liu, Z.; Zhang, X.S.; Zhang, S. Breast tumor subgroups reveal diverse clinical prognostic power. Sci. Rep. 2014, 4, 1-9. [CrossRef] [PubMed]

38. Riaz, S.K.; Saeed, M.; Malik, M.F.A. Clinical and therapeutic implications of histone acetylation in breast cancer. West Indian Med. J. 2016, 65, 337-344.

39. Guo, P.; Chen, W.; Li, H.; Li, M.; Li, L. The Histone Acetylation Modifications of Breast Cancer and their Therapeutic Implications. Pathol. Oncol. Res. 2018, 24, 807-813. [CrossRef] [PubMed]

40. Ediriweera, M.K.; Tennekoon, K.H.; Samarakoon, S.R. Emerging role of histone deacetylase inhibitors as anti-breast-cancer agents. Drug Discov. Today 2019, 24, 685-702. [CrossRef]

41. Garmpis, N.; Damaskos, C.; Garmpi, A.; Kalampokas, E.; Kalampokas, T.; Spartalis, E.; Daskalopoulou, A.; Valsami, S.; Kontos, M.; Nonni, A.; et al. Histone deacetylases as new therapeutic targets in triple-negative breast cancer: Progress and promises. Cancer Genom. Proteom. 2017, 14, 299-313.

42. Mann, B.S.; Johnson, J.R.; Cohen, M.H.; Justice, R.; Pazdur, R. FDA Approval Summary: Vorinostat for Treatment of Advanced Primary Cutaneous T-Cell Lymphoma. Oncologist 2007, 12, 1247-1252. [CrossRef] [PubMed]

43. Eleutherakis-Papaiakovou, E.; Kanellias, N.; Kastritis, E.; Gavriatopoulou, M.; Terpos, E.; Dimopoulos, M.A. Efficacy of Panobinostat for the Treatment of Multiple Myeloma. J. Oncol. 2020. [CrossRef]

44. Iyer, S.P.; Foss, F.F. Romidepsin for the Treatment of Peripheral T-Cell Lymphoma. Oncologist 2015, 20, 1084-1091. [CrossRef]

45. Lee, H.Z.; Kwitkowski, V.E.; Del Valle, P.L.; Ricci, M.S.; Saber, H.; Habtemariam, B.A.; Bullock, J.; Bloomquist, E.; Shen, Y.L.; Chen, X.H.; et al. FDA approval: Belinostat for the treatment of patients with relapsed or refractory peripheral T-cell lymphoma. Clin. Cancer Res. 2015, 21, 2666-2670. [CrossRef] [PubMed]

46. Glozak, M.A.; Sengupta, N.; Zhang, X.; Seto, E. Acetylation and deacetylation of non-histone proteins. Gene 2005, 363, 15-23. [CrossRef] [PubMed]

47. Spange, S.; Wagner, T.; Heinzel, T.; Krämer, O.H. Acetylation of non-histone proteins modulates cellular signalling at multiple levels. Int. J. Biochem. Cell Biol. 2009, 41, 185-198. [CrossRef] [PubMed]

48. Wang, Z.; Leng, Y.; Tsai, L.K.; Leeds, P.; Chuang, D.M. Valproic acid attenuates blood-brain barrier disruption in a rat model of transient focal cerebral ischemia: The roles of HDAC and MMP-9 inhibition. J. Cereb. Blood Flow Metab. 2011, 31, 52-57. [CrossRef] [PubMed]

49. Jang, E.R.; Lim, S.J.; Lee, E.S.; Jeong, G.; Kim, T.Y.; Bang, Y.J.; Lee, J.S. The histone deacetylase inhibitor trichostatin a sensitizes estrogen receptor $\alpha$-negative breast cancer cells to tamoxifen. Oncogene 2004, 23, 1724-1736. [CrossRef]

50. Chen, S.Y.; Zheng, X.W.; Cai, J.X.; Zhang, W.P.; You, H.S.; Xing, J.F.; Dong, Y.L. Histone deacetylase inhibitor reverses multidrug resistance by attenuating the nucleophosmin level through PI3K/Akt pathway in breast cancer. Int. J. Oncol. 2016, 49, 294-304. [CrossRef]

51. Lipska, K.; Gumieniczek, A.; Filip, A.A. Anticonvulsant valproic acid and other short-chain fatty acids as novel anticancer therapeutics: Possibilities and challenges. Acta Pharm. 2020, 70, 291-301. [CrossRef]

52. Romoli, M.; Mazzocchetti, P.; D'Alonzo, R.; Siliquini, S.; Rinaldi, V.E.; Verrotti, A.; Calabresi, P.; Costa, C. Valproic Acid and Epilepsy: From Molecular Mechanisms to Clinical Evidences. Curr. Neuropharmacol. 2018, 17, 926-946. [CrossRef] [PubMed]

53. Sanaei, M.; Kavoosi, F. Effect of Valproic Acid on the Class I Histone Deacetylase 1, 2 and 3, Tumor Suppressor Genes p21WAF1/CIP1 and p53, and Intrinsic Mitochondrial Apoptotic Pathway, Pro- (Bax, Bak, and Bim) and anti- (Bcl-2, Bcl-xL, and Mcl-1) Apoptotic Genes Expression, Ce. Asian Pacific J. Cancer Prev. 2021, 22, 89-95. [CrossRef] [PubMed]

54. Pang, B.; Zhang, J.; Zhang, X.; Yuan, J.; Shi, Y.; Qiao, L. Inhibition of lipogenesis and induction of apoptosis by valproic acid in prostate cancer cells via the C/EBP $\alpha /$ SREBP-1 pathway. Acta Biochim. Biophys. Sin. 2021, 53, 354-364. [CrossRef]

55. Jahani, M.; Khanahmad, H.; Nikpour, P. Evaluation of the Effects of Valproic Acid Treatment on Cell Survival and EpithelialMesenchymal Transition-Related Features of Human Gastric Cancer Cells. J. Gastrointest. Cancer 2020. [CrossRef]

56. Injinari, N.; Amini-Farsani, Z.; Yadollahi-Farsani, M.; Teimori, H. Apoptotic effects of valproic acid on miR-34a, miR-520h and HDAC1 gene in breast cancer. Life Sci. 2021, 269, 119027. [CrossRef]

57. Ozman, Z.; Ozbek Iptec, B.; Sahin, E.; Guney Eskiler, G.; Deveci Ozkan, A.; Kaleli, S. Regulation of valproic acid induced EMT by AKT/GSK3 $\beta / \beta$-catenin signaling pathway in triple negative breast cancer. Mol. Biol. Rep. 2021, 48, 1335-1343. [CrossRef] [PubMed]

58. Wawruszak, A.; Luszczki, J.J.; Kalafut, J.; Okla, K.; Halasa, M.; Rivero-Muller, A.; Stepulak, A. Additive pharmacological interaction between cisplatin (CDDP) and histone deacetylase inhibitors (HDIs) in MDA-MB-231 triple negative breast cancer (TNBC) cells with altered notch1 activity—an isobolographic analysis. Int. J. Mol. Sci. 2019, 20, 3663. [CrossRef] 
59. Wawruszak, A.; Luszczki, J.J.; Grabarska, A.; Gumbarewicz, E.; Dmoszynska-Graniczka, M.; Polberg, K.; Stepulak, A. Assessment of interactions between cisplatin and two histone deacetylase inhibitors in MCF7, T47D and MDA-MB-231 human breast cancer cell lines-An isobolographic analysis. PLoS ONE 2015, 10, e0143013. [CrossRef]

60. Fortunati, N.; Bertino, S.; Costantino, L.; Bosco, O.; Vercellinatto, I.; Catalano, M.G.; Boccuzzi, G. Valproic acid is a selective antiproliferative agent in estrogen-sensitive breast cancer cells. Cancer Lett. 2008, 259, 156-164. [CrossRef]

61. Aztopal, N.; Erkisa, M.; Erturk, E.; Ulukaya, E.; Tokullugil, A.H.; Ari, F. Valproic acid, a histone deacetylase inhibitor, induces apoptosis in breast cancer stem cells. Chem. Biol. Interact. 2018, 280, 51-58. [CrossRef]

62. Mawatari, T.; Ninomiya, I.; Inokuchi, M.; Harada, S.; Hayashi, H.; Oyama, K.; Makino, I.; Nakagawara, H.; Miyashita, T.; Tajima, H.; et al. Valproic acid inhibits proliferation of HER2-expressing breast cancer cells by inducing cell cycle arrest and apoptosis through Hsp70 acetylation. Int. J. Oncol. 2015, 47, 2073-2081. [CrossRef] [PubMed]

63. Zhang, S.; Tang, Z.; Qing, B.; Tang, R.; Duan, Q.; Ding, S.; Deng, D. Valproic acid promotes the epithelial-to-mesenchymal transition of breast cancer cells through stabilization of Snail and transcriptional upregulation of Zeb1. Eur. J. Pharmacol. $2019,865$. [CrossRef]

64. Wawruszak, A.; Gumbarewicz, E.; Okon, E.; Jeleniewicz, W.; Czapinski, J.; Halasa, M.; Okla, K.; Smok-Kalwat, J.; Bocian, A.; Rivero-Muller, A.; et al. Histone deacetylase inhibitors reinforce the phenotypical markers of breast epithelial or mesenchymal cancer cells but inhibit their migratory properties. Cancer Manag. Res. 2019, 11, 8345-8358. [CrossRef]

65. Li, G.F.; Qian, T.L.; Li, G.S.; Yang, C.X.; Qin, M.; Huang, J.; Sun, M.; Han, Y.Q. Sodium valproate inhibits MDA-MB-231 breast cancer cell migration by upregulating NM23H1 expression. Genet. Mol. Res. 2012, 11, 77-86. [CrossRef]

66. Fortunati, N.; Bertino, S.; Costantino, L.; De Bortoli, M.; Compagnone, A.; Bandino, A.; Catalano, M.G.; Boccuzzi, G. Valproic acid restores ER $\alpha$ and antiestrogen sensitivity to ER $\alpha$-negative breast cancer cells. Mol. Cell. Endocrinol. 2010, 314, 17-22. [CrossRef]

67. Zhou, X.; Li, Z.; Wang, X.; Jiang, G.; Shan, C.; Liu, S. Metabolomics reveals the effect of valproic acid on MCF-7 and MDA-MB-231 cells. Xenobiotica 2020, 50, 252-260. [CrossRef] [PubMed]

68. Han, W.; Zhang, C.; Cao, F.-Y.; Cao, F.; Jiang, L.; Ding, H.Z. Prognostic and clinicopathological value of NM23 expression in patients with breast cancer: A systematic review and meta-analysis. Curr. Probl. Cancer 2017, 41, 80-93. [CrossRef]

69. Mátyási, B.; Farkas, Z.; Kopper, L.; Sebestyén, A.; Boissan, M.; Mehta, A.; Takács-Vellai, K. The Function of NM23-H1/NME1 and Its Homologs in Major Processes Linked to Metastasis. Pathol. Oncol. Res. 2020, 26, 49-61. [CrossRef]

70. Das, V.; Bhattacharya, S.; Chikkaputtaiah, C.; Hazra, S.; Pal, M. The basics of epithelial-mesenchymal transition (EMT): A study from a structure, dynamics, and functional perspective. J. Cell. Physiol. 2019, 234, 14535-14555. [CrossRef] [PubMed]

71. Chaffer, C.L.; San Juan, B.P.; Lim, E.; Weinberg, R.A. EMT, cell plasticity and metastasis. Cancer Metastasis Rev. 2016, 35, 645-654. [CrossRef] [PubMed]

72. Kotiyal, S.; Bhattacharya, S. Breast cancer stem cells, EMT and therapeutic targets. Biochem. Biophys. Res. Commun. 2014, 453, 112-116. [CrossRef]

73. Song, K.; Farzaneh, M. Signaling pathways governing breast cancer stem cells behavior. Stem Cell Res. Ther. 2021, $12,245$. [CrossRef]

74. Kaszak, I.; Witkowska-Piłaszewicz, O.; Niewiadomska, Z.; Dworecka-Kaszak, B.; Toka, F.N.; Jurka, P. Role of cadherins in cancer-A review. Int. J. Mol. Sci. 2020, 21, 7624. [CrossRef] [PubMed]

75. Kar, R.; Jha, N.K.; Jha, S.K.; Sharma, A.; Dholpuria, S.; Asthana, N.; Chaurasiya, K.; Singh, V.K.; Burgee, S.; Nand, P. A “NOTCH” deeper into the epithelial-to-mesenchymal transition (EMT) program in breast cancer. Genes 2019, 10, 961. [CrossRef] [PubMed]

76. Nawshad, A.; Lagamba, D.; Hay, E.D. Transforming growth factor $\beta$ (TGF $\beta$ ) signalling in palatal growth, apoptosis and epithelial mesenchymal transformation (EMT). Arch. Oral Biol. 2004, 49, 675-689. [CrossRef] [PubMed]

77. Santibanez, J.F.; Obradović, H.; Kukolj, T.; Krstić, J. Transforming growth factor- $\beta$, matrix metalloproteinases, and urokinase-type plasminogen activator interaction in the cancer epithelial to mesenchymal transition. Dev. Dyn. 2018, 247, 382-395. [CrossRef] [PubMed]

78. Jaiswal, R.K.; Varshney, A.K.; Yadava, P.K. Diversity and functional evolution of the plasminogen activator system. Biomed. Pharmacother. 2018, 98, 886-898. [CrossRef]

79. Makena, M.R.; Gatla, H.; Verlekar, D.; Sukhavasi, S.; Pandey, M.K.; Pramanik, K.C. Wnt/ $\beta$-catenin signaling: The culprit in pancreatic carcinogenesis and therapeutic resistance. Int. J. Mol. Sci. 2019, 20, 4242. [CrossRef] [PubMed]

80. Lei, Y.; Chen, L.; Zhang, G.; Shan, A.; Ye, C.; Liang, B.; Sun, J.; Liao, X.; Zhu, C.; Chen, Y.; et al. MicroRNAs target the Wnt/ $\beta$-catenin signaling pathway to regulate epithelial-mesenchymal transition in cancer. Oncol. Rep. 2020, 44, 1299-1313. [CrossRef]

81. Su, C.M.; Wang, M.Y.; Hong, C.C.; Chen, H.A.; Su, Y.H.; Wu, C.H.; Huang, M.T.; Chang, Y.W.; Jiang, S.S.; Sung, S.Y.; et al. MiR-520h is crucial for DAPK2 regulation and breast cancer progression. Oncogene 2016, 35, 1134-1142. [CrossRef]

82. Hussen, B.M.; Shoorei, H.; Mohaqiq, M.; Dinger, M.E.; Hidayat, H.J.; Taheri, M.; Ghafouri-Fard, S. The Impact of Non-coding RNAs in the Epithelial to Mesenchymal Transition. Front. Mol. Biosci. 2021, 8. [CrossRef]

83. Pan, G.; Liu, Y.; Shang, L.; Zhou, F.; Yang, S. EMT-associated microRNAs and their roles in cancer stemness and drug resistance. Cancer Commun. 2021, 41, 199-217. [CrossRef] [PubMed]

84. Dong, B.; Li, S.; Zhu, S.; Yi, M.; Luo, S.; Wu, K. MiRNA-mediated EMT and CSCs in cancer chemoresistance. Exp. Hematol. Oncol. 2021, 10. [CrossRef] [PubMed] 
85. Lim, D.; Cho, J.G.; Yun, E.; Lee, A.; Ryu, H.Y.; Lee, Y.J.; Yoon, S.; Chang, W.; Lee, M.S.; Kwon, B.S.; et al. MicroRNA 34A-AXL axis regulates vasculogenic mimicry formation in breast cancer cells. Genes 2021, 12, 9. [CrossRef] [PubMed]

86. Lin, T.; Ren, Q.; Zuo, W.; Jia, R.; Xie, L.; Lin, R.; Zhao, H.; Chen, J.; Lei, Y.; Wang, P.; et al. Valproic acid exhibits anti-tumor activity selectively against EGFR/ErbB2/ErbB3-coexpressing pancreatic cancer via induction of ErbB family members-targeting microRNAs. J. Exp. Clin. Cancer Res. 2019, 38. [CrossRef]

87. Hu, S.; Liu, L.; Chang, E.B.; Wang, J.Y.; Raufman, J.P. Butyrate inhibits pro-proliferative miR-92a by diminishing c-Myc-induced miR-17-92a cluster transcription in human colon cancer cells. Mol. Cancer 2015, 14. [CrossRef]

88. Bellissimo, T.; Ganci, F.; Gallo, E.; Sacconi, A.; Tito, C.; De Angelis, L.; Pulito, C.; Masciarelli, S.; Diso, D.; Anile, M.; et al. Thymic Epithelial Tumors phenotype relies on miR-145-5p epigenetic regulation. Mol. Cancer 2017, 16. [CrossRef]

89. Rücker, F.G.; Lang, K.M.; Fütterer, M.; Komarica, V.; Schmid, M.; Döhner, H.; Schlenk, R.F.; Döhner, K.; Knudsen, S.; Bullinger, L. Molecular dissection of valproic acid effects in acute myeloid leukemia identifies predictive networks. Epigenetics 2016, 11, 517-525. [CrossRef] [PubMed]

90. Zhang, G.; Wang, J.; Zheng, R.; Song, B.; Huang, L.; Liu, Y.; Hao, Y.; Bai, X. MiR-133 Targets YES1 and Inhibits the Growth of Triple-Negative Breast Cancer Cells. Technol. Cancer Res. Treat. 2020, 19. [CrossRef]

91. Shen, Y.; Xu, Y.; Huang, L.; Chi, Y.; Meng, L. MiR-205 suppressed the malignant behaviors of breast cancer cells by targeting CLDN11 via modulation of the epithelial-to-mesenchymal transition. Aging 2021, 13. [CrossRef]

92. Chernyi, V.S.; Tarasova, P.V.; Kozlov, V.V.; Saik, O.V.; Kushlinskii, N.E.; Gulyaeva, L.F. Search of MicroRNAs Regulating the Receptor Status of Breast Cancer In Silico and Experimental Confirmation of Their Expression in Tumors. Bull. Exp. Biol. Med. 2017, 163, 655-659. [CrossRef] [PubMed]

93. Cun, J.; Yang, Q. Bioinformatics-based interaction analysis of miR-92a-3p and key genes in tamoxifen-resistant breast cancer cells. Biomed. Pharmacother. 2018, 107, 117-128. [CrossRef] [PubMed]

94. Tang, W.; Zhang, X.; Tan, W.; Gao, J.; Pan, L.; Ye, X.; Chen, L.; Zheng, W. miR-145-5p Suppresses Breast Cancer Progression by Inhibiting SOX 2 . J. Surg. Res. 2019, 236, 278-287. [CrossRef]

95. Chaudhary, S.; Islam, Z.; Mishra, V.; Rawat, S.; Ashraf, G.M.; Kolatkar, P.R. Sox 2 : A Regulatory Factor in Tumorigenesis and Metastasis. Curr. Protein Pept. Sci. 2019, 20, 495-504. [CrossRef] [PubMed]

96. Patel, N.; Garikapati, K.R.; Ramaiah, M.J.; Polavarapu, K.K.; Bhadra, U.; Bhadra, M.P. miR-15a/miR-16 induces mitochondrial dependent apoptosis in breast cancer cells by suppressing oncogene BMI1. Life Sci. 2016, 164, 60-70. [CrossRef]

97. Heers, H.; Stanislaw, J.; Harrelson, J.; Lee, M.W. Valproic acid as an adjunctive therapeutic agent for the treatment of breast cancer. Eur. J. Pharmacol. 2018, 835, 61-74. [CrossRef] [PubMed]

98. Olsen, C.M.; Meussen-Elholm, E.T.M.; Røste, L.S.; Taubøll, E. Antiepileptic drugs inhibit cell growth in the human breast cancer cell line MCF7. Mol. Cell. Endocrinol. 2004, 213, 173-179. [CrossRef]

99. Tayanloo-Beik, A.; Sarvari, M.; Payab, M.; Gilany, K.; Alavi-Moghadam, S.; Gholami, M.; Goodarzi, P.; Larijani, B.; Arjmand, B. OMICS insights into cancer histology; Metabolomics and proteomics approach. Clin. Biochem. 2020, 84, 13-20. [CrossRef]

100. Sarin, N.; Engel, F.; Rothweiler, F.; Cinatl, J.; Michaelis, M.; Frötschl, R.; Fröhlich, H.; Kalayda, G. Key Players of Cisplatin Resistance: Towards a Systems Pharmacology Approach. Int. J. Mol. Sci. 2018, 19, 767. [CrossRef] [PubMed]

101. Al-malky, H.S.; Al Harthi, S.E.; Osman, A.M.M. Major obstacles to doxorubicin therapy: Cardiotoxicity and drug resistance. J. Oncol. Pharm. Pract. 2020, 26, 434-444. [CrossRef]

102. Alfarouk, K.O.; Stock, C.M.; Taylor, S.; Walsh, M.; Muddathir, A.K.; Verduzco, D.; Bashir, A.H.H.; Mohammed, O.Y.; Elhassan, G.O.; Harguindey, S.; et al. Resistance to cancer chemotherapy: Failure in drug response from ADME to P-gp. Cancer Cell Int. 2015, 15, 71. [CrossRef] [PubMed]

103. Okon, E.; Luszczki, J.J.; Kukula-Koch, W.; Halasa, M.; Jarzab, A.; Khurelbat, D.; Stepulak, A.; Wawruszak, A. Synergistic or Additive Pharmacological Interactions between Magnoflorine and Cisplatin in Human Cancer Cells of Different Histological Origin. Int. J. Mol. Sci. 2020, 21, 2848. [CrossRef] [PubMed]

104. Kukula-Koch, W.; Grabarska, A.; Łuszczki, J.; Czernicka, L.; Nowosadzka, E.; Gumbarewicz, E.; Jarząb, A.; Audo, G.; Upadhyay, S.; Głowniak, K.; et al. Superior anticancer activity is demonstrated by total extract of Curcuma longa L. as opposed to individual curcuminoids separated by centrifugal partition chromatography. Phyther. Res. 2018, 32, 933-942. [CrossRef] [PubMed]

105. Wróblewska-łuczka, P.; Grabarska, A.; Łuszczki, J.J.; Florek-łuszczki, M.; Plewa, Z. Synergy, additivity, and antagonism between cisplatin and selected coumarins in human melanoma cells. Int. J. Mol. Sci. 2021, 22, 537. [CrossRef] [PubMed]

106. Jarzab, A.; Luszczki, J.; Guz, M.; Skalicka-Wozniak, K.; Halasa, M.; Smok-Kalwat, J.; Polberg, K.; Stepulak, A. Combination of osthole and cisplatin against rhabdomyosarcoma TE671 cells yielded additive pharmacologic interaction by means of isobolographic analysis. Anticancer Res. 2018, 38, 205-210. [PubMed]

107. Dasari, S.; Bernard Tchounwou, P. Cisplatin in cancer therapy: Molecular mechanisms of action. Eur. J. Pharmacol. 2014, 740, 364-378. [CrossRef]

108. Minegaki, T.; Suzuki, A.; Mori, M.; Tsuji, S.; Yamamoto, S.; Watanabe, A.; Tsuzuki, T.; Tsunoda, T.; Yamamoto, A.; Tsujimoto, M.; et al. Histone deacetylase inhibitors sensitize 5-fluorouracil-resistant MDA-MB-468 breast cancer cells to 5-fluorouracil. Oncol. Lett. 2018, 16, 6202-6208. [CrossRef]

109. Terranova-Barberio, M.; Roca, M.S.; Zotti, A.I.; Leone, A.; Bruzzese, F.; Vitagliano, C.; Scogliamiglio, G.; Russo, D.; D’Angelo, G.; Franco, R.; et al. Valproic acid potentiates the anticancer activity of capecitabine in vitro and in vivo in breast cancer models via induction of thymidine phosphorylase expression. Oncotarget 2016, 7, 7715-7731. [CrossRef] 
110. Arakawa, Y.; Saito, S.; Yamada, H.; Aiba, K. Simultaneous treatment with camptothecin and valproic acid suppresses induction of Bcl-XL and promotes apoptosis of MCF-7 breast cancer cells. Apoptosis 2009, 14, 1076-1085. [CrossRef]

111. Phillips, S.L.; Williams, C.B.; Zambrano, J.N.; Williams, C.J.; Yeh, E.S. Connexin 43 in the development and progression of breast cancer: What's the connection? Int. J. Oncol. 2017, 51, 1005-1013. [CrossRef]

112. Sargazi, S.; Kooshkaki, O.; Zavar Reza, J.; Saravani, R.; Zarei Jaliani, H.; Mirinejad, S.; Meshkini, F. Mild antagonistic effect of Valproic acid in combination with AZD2461 in MCF-7 breast cancer cells. Med. J. Islamic Repub. Iran 2019, 33, 29. [CrossRef]

113. Soldi, R.; Cohen, A.L.; Cheng, L.; Sun, Y.; Moos, P.J.; Bild, A.H. A genomic approach to predict synergistic combinations for breast cancer treatment. Pharm. J. 2013, 13, 94-104. [CrossRef]

114. Ponce-Cusi, R.; Calaf, G.M. Apoptotic activity of 5-fluorouracil in breast cancer cells transformed by low doses of ionizing $\alpha$-particle radiation. Int. J. Oncol. 2016, 48, 774-782. [CrossRef] [PubMed]

115. Varshavsky-Yanovsky, A.N.; Goldstein, L.J. Role of Capecitabine in Early Breast Cancer. J. Clin. Oncol. 2020, 38, 179-182. [CrossRef]

116. Zunino, F.; Pratesi, G. Camptothecins in clinical development. Expert Opin. Investig. Drugs 2004, 13, 269-284. [CrossRef]

117. Ulukan, H.; Swaan, P.W. Camptothecins: A review of their chemotherapeutic potential. Drugs 2002, 62, 2039-2057. [CrossRef]

118. Lovitt, C.J.; Shelper, T.B.; Avery, V.M. Doxorubicin resistance in breast cancer cells is mediated by extracellular matrix proteins. BMC Cancer 2018, 18. [CrossRef] [PubMed]

119. Christowitz, C.; Davis, T.; Isaacs, A.; Van Niekerk, G.; Hattingh, S.; Engelbrecht, A.M. Mechanisms of doxorubicin-induced drug resistance and drug resistant tumour growth in a murine breast tumour model. BMC Cancer 2019, 19, 757. [CrossRef] [PubMed]

120. Tong, X.H.; Zheng, C.; Jiang, G.J.; Dong, S.Y. Sodium valproate enhances doxorubicin cytotoxicity in breast cancer cells in vitro. Nan Fang Yi Ke Da Xue Xue Bao 2015, 35, 62-65. Available online: https:/ / pubmed.ncbi.nlm.nih.gov/25613611/ (accessed on 21 April 2021).

121. Muñoz, A.M.; Fragoso-Vázquez, M.J.; Martel, B.P.; Chávez-Blanco, A.; Dueñas-González, A.; García-Sánchez, J.R.; Bello, M.; Romero-Castro, A.; Correa-Basurto, J. Targeting Breast Cancer Cells with G4 PAMAM Dendrimers and Valproic Acid Derivative Complexes. Anticancer Agents Med. Chem. 2020, 20, 1857-1872. [CrossRef]

122. Ribociclib\&Belinostat in Patients W Metastatic Triple Neg Breast Cancer \& Recurrent Ovarian Cancer W Response Prediction by Genomics. Available online: https:/ / clinicaltrials.gov/ct2/show / NCT04315233?term=Histone+deacetylase+inhibitor\&cond= Breast+Cancer\&draw $=3 \&$ rank $=5$ (accessed on 17 June 2021).

123. Pembrolizumab and Tamoxifen with or without Vorinostat for the Treatment of Estrogen Receptor Positive Breast Cancer. Available online: https: / / clinicaltrials.gov/ct2/show / NCT04190056?term=Histone+deacetylase+inhibitor\&cond=Breast + Cancer\& draw $=3$ (accessed on 17 June 2021).

124. A Pilot Study of the Combination of Entinostat With Capecitabine in High Risk Breast Cancer After Neo-adjuvant Therapy. Available online: https: / / clinicaltrials.gov / ct2/ show /NCT03473639?term=Histone+deacetylase+inhibitor\&cond=Breast+Cancer\& draw=3\&rank=36 (accessed on 17 June 2021).

125. Talazoparib in Combination With Belinostat for Metastatic Breast Cancer, Metastatic Castration Resistant Prostate Cancer, and Metastatic Ovarian Cancer. Available online: https:/ / linicaltrials.gov/ct2/show / NCT04703920?term=Histone+deacetylase+ inhibitor\&cond=Breast+Cancer\&draw=3\&rank=32 (accessed on 17 June 2021).

126. BN-Brachyury, Entinostat, Adotrastuzumab Emtansine and M7824 in Advanced Stage Breast Cancer (BrEAsT). Available online: https:/ / clinicaltrials.gov / ct2 / show / NCT04296942? term=Histone+deacetylase+inhibitor\&cond=Breast + Cancer\&draw= $3 \&$ rank $=17$ (accessed on 17 June 2021).

127. Olaparib in Combination With Vorinostat in Patients With Relapsed/Refractory and/or Metastatic Breast Cancer. Available online: https: / / clinicaltrials.gov / ct2 / show / NCT03742245?term=Histone+deacetylase+inhibitor\&cond=Breast+Cancer\&draw= $3 \&$ rank $=11$ (accessed on 17 June 2021).

128. Münster, P.; Marchion, D.; Bicaku, E.; Schmitt, M.; Ji, H.L.; DeConti, R.; Simon, G.; Fishman, M.; Minton, S.; Garrett, C.; et al. Phase I trial of histone deacetylase inhibition by valproic acid followed by the topoisomerase II inhibitor epirubicin in advanced solid tumors: A clinical and translational study. J. Clin. Oncol. 2007, 25, 1979-1985. [CrossRef]

129. Munster, P.; Marchion, D.; Bicaku, E.; Lacevic, M.; Kim, J.; Centeno, B.; Daud, A.; Neuger, A.; Minton, S.; Sullivan, D. Clinical and biological effects of valproic acid as a histone deacetylase inhibitor on tumor and surrogate tissues: Phase i/ii trial of valproic acid and epirubicin/FEC. Clin. Cancer Res. 2009, 15, 2488-2496. [CrossRef]

130. Arce, C.; Pérez, C.; González-Fierro, A.; de la Cruz-Hernńdez, E.; Revilla-Vázquez, A.; Chávez-Blanco, A.; Trejo-Becerril, C.; Pérez-Cárdenas, E.; Taja-Chayeb, L.; Bargallo, E.; et al. A proof-of-principle study of epigenetics therapy added to neoadjuvant doxorubicin cyclophosphamide for locally advanced breast cancer. PLoS ONE 2006, 1, e98. [CrossRef] [PubMed]

131. Bevacizumab and Temsirolimus Alone or in Combination With Valproic Acid or Cetuximab in Treating Patients With Advanced or Metastatic Malignancy or Other Benign Disease. Available online: https:/ / clinicaltrials.gov/ct2/show/study/NCT01552434? term=valproic+acid+and+breast+cancer\&draw $=2 \&$ rank $=7$ (accessed on 17 June 2021).

132. Fardi, M.; Solali, S.; Farshdousti Hagh, M. Epigenetic mechanisms as a new approach in cancer treatment: An updated review. Genes Dis. 2018, 5, 304-311. [CrossRef] [PubMed]

133. Souza, C.; Chatterji, B. HDAC Inhibitors as Novel Anti-Cancer Therapeutics. Recent Pat. Anticancer Drug Discov. 2015, 10, 145-162. [CrossRef] 
134. Diederich, M.; Chateauvieux, S.; Morceau, F.; Dicato, M. Molecular and therapeutic potential and toxicity of valproic acid. J. Biomed. Biotechnol. 2010, 2010. [CrossRef]

135. Činčárová, L.; Zdráhal, Z.; Fajkus, J. New perspectives of valproic acid in clinical practice. Expert Opin. Investig. Drugs 2013, 22, 1535-1547. [CrossRef]

136. Goyal, J.; Rodriguez, R. Evidence from clinical trials for the use of valproic acid in solid tumors: Focus on prostate cancer. Clin. Investig. 2013, 3, 467-478. [CrossRef]

137. Duenas-Gonzalez, A.; Candelaria, M.; Perez-Plascencia, C.; Perez-Cardenas, E.; de la Cruz-Hernandez, E.; Herrera, L.A. Valproic acid as epigenetic cancer drug: Preclinical, clinical and transcriptional effects on solid tumors. Cancer Treat. Rev. 2008, 34, 206-222. [CrossRef]

138. Ponzano, A.; Tiboni, G.M. Teratology of valproic acid: An updated review of the possible mediating mechanisms. Minerva Ginecol. 2018, 70, 303-322.

139. Meisel, J.L.; Venur, V.A.; Gnant, M.; Carey, L. Evolution of Targeted Therapy in Breast Cancer: Where Precision Medicine Began. Am. Soc. Clin. Oncol. Educ. B 2018, 38, 78-86. [CrossRef]

140. Dhritlahre, R.K.; Saneja, A. Recent advances in HER2-targeted delivery for cancer therapy. Drug Discov. Today 2020. [CrossRef]

141. Mitsogianni, M.; Trontzas, I.P.; Gomatou, G.; Ioannou, S.; Syrigos, N.K.; Kotteas, E.A. The changing treatment of metastatic her2-positive breast cancer. Oncol. Lett. 2021, 21. [CrossRef] [PubMed]

142. Catalano, M.G.; Fortunati, N.; Pugliese, M.; Poli, R.; Bosco, O.; Mastrocola, R.; Aragno, M.; Boccuzzi, G. Valproic acid, a histone deacetylase inhibitor, enhances sensitivity to doxorubicin in anaplastic thyroid cancer cells. J. Endocrinol. 2006, 191, 465-472. [CrossRef] [PubMed] 